2

3

\title{
Geo-climatic gradient shapes functional trait variations in Salix eriocephala Michx.
}

Arun S.K. Shunmugam ${ }^{1}$, Raju Y. Soolanayakanahally ${ }^{1,2^{*}}$, Robert D. Guy ${ }^{3}$

1. Saskatoon Research and Development Centre, Agriculture and Agri-Food Canada, Saskatoon, Saskatchewan, S7N 0X2, Canada

2. Indian Head Research Farm, Agriculture and Agri-Food Canada, Indian Head, Saskatchewan, S0G 2K0, Canada

3. Department of Forest and Conservation Sciences, Faculty of Forestry, University of British Columbia, Forest Sciences Centre, 2424 Main Mall, Vancouver, BC V6T 1Z4, Canada.

*Corresponding author: Raju Soolanayakanahally

Phone: 1-306 3859585

Fax: $1-3063859482$

E-mail: raju.soolanayakanahally@agr.gc.ca

Key-words: Salix, photosynthesis, stomatal density, phenology, mesophyll conductance

Running title: Phenotypic variation of biomass willow 
47 Intraspecific variations in seasonal phenology and growth physiology reflect adaptation to local

\section{ABSTRACT} climate. To explore the patterns of local adaptation along latitudinal and longitudinal clines, we used thirty-four populations of Salix eriocephala sourced from its natural ranges across Canada. The genotypes were examined for 6 phenology and 19 ecophysiology traits over two growing seasons under common garden condition. Photosynthetic assimilation rate $(A)$ increased with increase in latitude when measured during free growth. In spite, the negative correlation between stomatal density and stomatal conductance $\left(g_{\mathrm{s}}\right)$, higher $A$ is facilitated via larger pore length among genotypes from short growing seasons. In addition, higher $A$, was positively associated with total leaf nitrogen and leaf mass per unit area. No population level differences were observed for water use-efficiency $\left(\Delta^{13} \mathrm{C}\right)$, however nitrogen isotope discrimination $\left(\delta^{15} \mathrm{~N}\right)$ displayed latitudinal clines. Growing season phenological traits considered in this study accounted high heritability $\left(H^{2}=0.65-0.94\right)$. Melampsora rust infestation also displayed a strong latitudinal cline with high-latitude genotypes being more susceptible. Overall, the results support the hypothesis that functional trait variations are largely explained by climate of origin and facilitate selection of parents with superior adaptive traits in the Canadian willow improvement program for bioenergy and environmental applications.

3

4

5

6

7

8

9

0

1

2

3

4

5




\section{INTRODUCTION}

77 The issue of local adaptation is a crucial problem in the view of climate change. Functional trait variation can provide insights into the physiological processes associated with a species' persistence across a range of environmental conditions resulting from local adaptation (Aitken and Whitlock 2013). Largely, local adaptation plays a significant role in maintaining genetic variation among plant populations (Hodkinson 1999), and to better understand the evolutionary mechanisms of local adaptation one needs to take into account the environmental factors that contribute to phenotypic variation in nature (Manzano-Piedras et al. 2014). Such divergent selection is tested using provenance trail or common garden approaches to better understand trait trade-off relationships (Stearns 1989). Hence, between-provenance variation probably represents the most powerful tool for testing hypotheses of climatic adaptation among perennial trees (Mátyás 1996), whereby environmental gradients have produced genetically based clinal patterns in phenotype through adaptive evolution.

Correlations between trait variation and geo-climatic factors may suggest the adaptive selection pressure exerted on a trait, thus demonstrating its adaptive significance. A negative latitudinal cline in tree height growth has been reported for deciduous (McKown et al. 2014a) and conifer seeds sourced from different provenances (Benomar et al. 2016). Although the height growth of trees is limited by growing conditions at high latitudes, it is not the case at low latitudes. Hence, the date of growth cessation is more important in differentiating among provenances height growth variations (Bridgewater 1990). Such trade-offs results from physiological and/or genetic links between traits and limit the possibility of evolution of beneficial traits (Weih 2003).

Starting with the classical work by Mooney and Billings (1961) on Oxyra digyna, studies have revealed population genetic differentiation in photosynthesis which follows latitudinal and/or elevational clines (Chapin and Oechel 1983, Robakowski et al. 2012). At the same time, Flood et al (2011) linked leaf morphological attributes (leaf thickness, stomatal densities, leaf nitrogen) influencing photosynthetic rates among ecotypes from diverse temperature and moisture regimes. Stomatal density and pore length determine maximum conductance of $\mathrm{CO}_{2}$ to the site of assimilation and also control transpirational water loss from leaves. Over the last 400-million 
107

108

109

110

111

112

113

114

115

116

117

118

119

120

121

122

123

124

125

126

127

128

129

130

131

132

133

134

135

136

137

rates and enabling land plants to occupy vast geographic ranges with varying environments thus contributing to increased genetic diversity (Franks and Beerling 2009). A strong association among traits suggests that optimization of photosynthesis to local environment along a latitudinal gradient is one mechanism by which plant fitness is enhanced (Gornall and Guy 2007).

Populus species sampled over vast geographic ranges are well studied for their intraspecific variation in seasonal phenology and ecophysiology related traits (e.g., Soolanayakanahally et al. 2009, McKown et al. 2014a). However, this remains less investigated in native populations of Salix (willow) species adapted to varied growth habitats. For example, willows from varied habitats provided evidence for their differential expression of water usage strategies when subjected to drought stress under greenhouse conditions (Savage and Cavender-Bares 2011). The physiological, anatomical and biochemical processes driving genotypic variation in resource acquisition and use efficiencies are still elusive in willows. $\Delta^{13} \mathrm{C}$ is a time integrated proxy measure of intrinsic water-use efficiency $\left(W U E_{\mathrm{i}}\right)$ and has been correlated to growth and biomass accumulation (Farquhar et al. 1989). Considerable genotypic variation in $\Delta^{13} \mathrm{C}$ has been reported within the genus Populus (Soolanayakanahally et al. 2009, Broeckx et al. 2014, McKown et al. 2014a) and in other tree species (Guy and Holowachuk 2001). These studies suggest that genetic variation in $\Delta^{13} \mathrm{C}$ is useful as a selection criterion for improved water-use efficiency. Observed genotypic differences in stomatal and mesophyll conductance to $\mathrm{CO}_{2}\left(g_{\mathrm{s}}\right.$ and $g_{\mathrm{m}}$, respectively) were reported to affect $\Delta^{13} \mathrm{C}$ (Gresset et al. 2014, Barbour et al. 2015). In addition, leaf anatomy (and its association with LMA), aquaporin activity and enzymatic processes (carbonic anhydrase, RuBisCO) have recently been shown to influence $g_{\mathrm{m}}$ (Muir et al. 2014, Flexas et al. 2006).

In crop plants, the natural abundance of stable $\mathrm{N}$ isotopes $\left(\delta^{15} \mathrm{~N}\right)$ appears to be influenced by soil water availability and together $\Delta^{13} \mathrm{C}$ and $\delta^{15} \mathrm{~N}$, has been proposed as an integrative measure for plant resource use-efficiency (Lopes et al. 2006). Lately, there are growing concerns over potential effects of soil-derived inorganic $\mathrm{N}$ [ammonium $\left(\mathrm{NH}_{4}^{+}\right)$and nitrate $\left(\mathrm{NO}_{3}{ }^{-}\right)$] affecting riparian systems and Kohl et al. (1971) established a negative relationship between $\mathrm{NO}_{3}{ }^{-}$and $\delta^{15} \mathrm{~N}$ to provide an insight into $\mathrm{N}$ uptake and assimilation by plants. With growing interest to establish Populus and Salix species as bioenergy crops in riparian buffer systems for nutrient interception and uptake along field edges, it is vital to investigate intraspecific variations in 
138

139

140

141

142

143

144

145

146

147

148

149

150

151

152

153

154

155

156

157

158

159

160

161

162

163

164

165

166

167

168

nitrogen isotope discrimination $\left(\delta^{15} \mathrm{~N}\right)$. Except for the study in P. balsamifera by Kalcsits and Guy (2016), no other studies exploited intraspecific variations in $\delta^{15} \mathrm{~N}$. In addition, one could improve nitrogen use efficiency (NUE) by understanding plant $\mathrm{N}$ uptake, assimilation and remobilization (between sink and source) during the growing season. These measures of resource use-efficiencies need careful interpretation, as they are confounded to common garden artefacts (Soolanayakanahally et al. 2015).

Seasonal phenologies among deciduous trees in boreal and temperate regions are conditioned by the environment, especially by photoperiod and temperature. Bud phenology of boreal trees is characterized by spring bud break (bud flush) and summer growth cessation followed by leaf senescence in autumn (Fig. 1). The latter two events are cued by photoperiod (Fracheboud et al. 2009) and have an adaptive significance displaying highest heritability (Alberto et al. 2013). As photoperiod regime is precisely the same from year-to-year, one can calculate critical photoperiod from observational data given the calendar date and latitude (Withrow, 1959). For example, Howe et al. (1995) reported that a northern $P$. trichocarpa ecotype $\left(53^{\circ} \mathrm{N}\right)$ ceased height growth and set terminal bud to a critical photoperiod of $15 \mathrm{~h}$, whereas for a southern ecotype $\left(40^{\circ} \mathrm{N}\right)$ the critical photoperiod was $9 \mathrm{~h}$. Quite similarly, cold hardiness development displays latitudinal clines during spring and fall in Tamarix and Populus spp. (Friedman et al. 2011). An earlier bud set among high latitude trees might result in severe infestation of Melampsora leaf rust in a common garden setting due to natural selection trade-offs between growth phenology and disease resistance (McKown et al. 2014b).

Given the emergence of willows for biomass, bioenergy and environmental applications, many genetic resources are currently being made available in North America (Smart and Cameron 2008) and Europe (Lindegaard and Barker 1997) for detailed investigation of phenotypic variation. One such Canadian genetic resource is the AgCanSalix (Agriculture Canada Salix) collection comprising both native and hybrid willows. Canada has 76 native willow species which are adapted to a wide range of environmental conditions (Argus 2010). The diamond or heart-leaf willow, S. eriocephala Michx., spans a broad geographic range coupled with diverse climatic conditions (Dorn 1970), whereby selective pressure on growth physiology and seasonal phenology traits is expected to vary extensively. 
170 Considerable intraspecific variation in growth phenology and genetic diversity was documented

171 by earlier studies in Salix species that are highly correlated with their latitude of origin and/or

172 growing season length (Weih et al. 2011, Trybush et al. 2012, Berlin et al. 2014, and Pucholt et

173 al. 2015). Quantitative Trait Loci (QTLs) associated with growth phenology traits such as bud

174 burst, elongation growth and leaf abscission were identified in Salix spp. (Ghelardini et al. 2014).

175 Through association mapping analysis significant associations for bud burst, leaf senescence and

176 biomass traits were reported in S. viminalis (Hallingback et al. 2015).

177

178

In the present study, we investigated the factors that govern local adaptation by making use of a subset of 34 natural populations of $S$. eriocephala. We hypothesize that the gradient in climatic conditions (frost free days, mean annual precipitation, mean summer temperature) provide selection to favor the populations to respond differentially in functional traits (phenology, photosynthesis, resource use-efficiency) resulting from local genetic adaptation. The specific questions addressed are:

184 (i) Do latitudinal clines exist in photosynthetic assimilation rate $(A)$ among genotypes

(ii) Is there variation in water use-efficiency as shown by $\delta^{13} \mathrm{C}$ and nitrogen discrimination as shown by $\delta^{15} \mathrm{~N}$ ?

(iii) Is there a relationship in seasonal phenology and rust infestation among S. eriocephala

\section{MATERIALS AND METHODS} AgCanSalix collection

During the winter of 2012 (January to April) dormant stem cuttings of S. eriocephala were

197 collected from within the natural range of the species within Canada. In total, we sampled 34 198 populations with 15 genotypes per population $(N=510$, Fig. 1$)$. Care was taken to avoid clonal 
200

201

202

203

204

205

206

207

208

209

210

211

212

213

214

215

216

217

218

219

220

221

222

223

224

225

226

227

228

229

230

$\mathrm{km}$ apart without phenotypic bias. Dormant cuttings ( $20 \mathrm{~cm}$ long) were bagged separately for each of the 34 populations in re-sealable Ziploc ${ }^{\circledR}$ bags and stored at $-4^{\circ} \mathrm{C}$. Global Information System (GIS) coordinates and other site information were noted for each genotype (Table 1). This in situ collection of $S$. eriocephala along with other native species such as $S$. amygdaloides Andersson., S. bebbiana Sarg., S. discolor Muhl., S. interior Rowlee., and S. petiolaris Sm. is commonly referred to as the AgCanSalix collection (Agriculture Canada $\underline{\text { Salix }}$ ).

In spring (mid-May), 8-10 cm long dormant cuttings were forced to root in Spencer-Lemaire rootrainers (Beaver Plastics, Acheson, Canada) using a mixture of Sunshine No.2 (Sun Gro Horticulture, Vancouver, Canada) growing mix (60\%), peat (30\%) and vermiculite (10\%) inside a greenhouse under natural light. Greenhouse conditions were set to day/night temperatures of 23/18 ${ }^{\circ} \mathrm{C}$, respectively, with relative humidity at 40\%. The Agriculture and Agri-Food Canada (AAFC) greenhouse facility is located at Indian Head, Saskatchewan $\left(50.52^{\circ} \mathrm{N} 103.68^{\circ} \mathrm{W}\right.$; elevation $605 \mathrm{~m}$ ). Upon bud flush, the plants were regularly watered and fertilized using Hoagland's solutions at a $\mathrm{pH}$ adjusted to 5.8-6.3. After two months of greenhouse growth ( $25-30 \mathrm{~cm}$ tall), the plants were transferred to a shade house and allowed to undergo natural senescence. In late-October, the frozen root plugs were individually bagged and stored at $-4^{\circ} \mathrm{C}$ till the following spring.

\section{Common garden establishment}

At Indian Head, the site assigned for the establishment of common garden was left fallow during the 2012 summer. In September, nine soil cores were randomly taken from 0-15 cm depth using an auger to acquire a representative sample along the length of the common garden ( 3 acres). Upon air drying the soil cores were processed separately, bagged and sent for soil testing at AGVISE laboratories (Northwood, ND, USA). The soil texture was sandy clay loam with an average $\mathrm{pH}$ of 7.9 and with 13.6, 19.7, $242.9 \mathrm{ppm}$ of $\mathrm{N}, \mathrm{P}$ and $\mathrm{K}$ nutrients, respectively. A detailed soil test report is provided in Supplementary table ST1.

In spring 2013, the site preparation involved cultivating to a depth of $20 \mathrm{~cm}$ or more and disking. Later, the rows were marked at 3 metre intervals in East-West orientation, with each row running $320 \mathrm{~m}$ long. Based on the soil test report, necessary soil amendments were made by drenching 
231 the marked rows using micronutrient solutions followed by roto-tilling. Rows were mulched

232 using black plastic sheet (Crawling Valley Plastics, Bassano, AB, Canada) to avoid intra-row

233 weed competition. The frozen root plugs were taken out of cold storage and all fifteen genotypes

234 from each population were planted on mulched rows as a block with $1.0 \mathrm{~m}$ spacing. In each of

235 the three replicates, population blocks were randomized with 3 ramets per genotype planted side-

236 by-side. In addition, the common garden hosted a gene bank with a single ramet from 34

237 populations, totalling to 10 ramets for each genotype $(N=5100)$. The site was sprinkler irrigated

238 as necessary during summer months with mechanical weed control between rows. All trees

239 survived the first field growing season. A picture narrative of site preparation and planting is

240 provided in Supplementary Fig. SF1.

\section{Seasonal growth phenology}

243

Adopting the phenology timetable developed by Saska and Kuzovkina (2010) for Salix, bud flush and leaf emergence were monitored in 2014, while leaf senescence and leaf drop were monitored in 2013 and 2014. Phenology was monitored by the same personnel walking through the gene bank every day during spring and twice a week during summer and fall. The Melampsora rust disease onset and severity of infection was scored on all genotypes beginning mid-August to late-September following the narrative by Mckown et al. (2014b). Here, we report the Melampsora rust scores for the week prior to September $21^{\text {st }}$. Green cover duration (GCD; days) was calculated as the difference between days to leaf senescence and days to leaf emergence. Final height and non-coppiced stem dry biomass were recorded in November 2014. height gain.

256

\section{Screening for morpho-physiological traits}

258 Towards gas exchange measurements, we used a subset of 10 randomly chosen genotypes per 259 population with the exception of Easterville (EAS) where only eight were used $(N=338)$. The 260 measurements were made between $5^{\text {th }}$ July and $31^{\text {st }}$ July 2014 during active growth without 261 water deficit as our common garden was installed with a sprinkler irrigation system. All gas 
262

263

264

265

266

267

268

269

270

271

272

273

274

275

276

277

278

279

280

281

282

283

284

285

286

287

288

289

290

291

292

exchange measurements were done on clear, sunny days. Briefly, a Li-COR 6400 XTR (LI-COR Biosciences, Lincoln, NE, USA) portable infra-red gas exchange system was used for gas exchange measurements. The gas exchange equipment was switched on by 8:00 am every morning at the common garden location and allowed to stabilize for 30 min prior to recording. On any given day, gas exchange measurements were recorded on a single leaf per genotype between 8:30 and 11:45 am, with the measurement plant randomized among populations and days of measurement. Inside the leaf chamber, the following conditions were maintained: reference $\mathrm{CO}_{2}$ concentration set to 400 ppm using $\mathrm{CO}_{2}$ cartridges; flow rate $500 \mu \mathrm{mol} \mathrm{s}{ }^{-1}$; block temperature set at $23{ }^{\circ} \mathrm{C}$; relative humidity of incoming air adjusted to $\sim 50-55 \%$; photosynthetic active radiation (PAR) $1000 \mu \mathrm{mol} \mathrm{m} \mathrm{m}^{-2} \mathrm{~s}^{-1}$. Maximum photosynthetic assimilation rate $(A, \mu \mathrm{mol}$ $\left.\mathrm{CO}_{2} \mathrm{~m}^{-2} \mathrm{~s}^{-1}\right)$, stomatal conductance $\left(g_{\mathrm{s}}, \mathrm{mol} \mathrm{H}_{2} \mathrm{O} \mathrm{m} \mathrm{m}^{-2} \mathrm{~s}^{-1}\right)$, transpiration rate $\left(E\right.$, $\mathrm{mmol} \mathrm{H}_{2} \mathrm{O} \mathrm{m}^{-2}$ $\left.\mathrm{s}^{-1}\right)$ and intercellular $\mathrm{CO}_{2}$ concentration $\left(C_{\mathrm{i}}, \mathrm{ppm}\right)$ were measured on fully expanded leaves. The intrinsic water-use efficiency $\left(W U E_{\mathrm{i}}\right)$ was determined by calculating $A / g_{\mathrm{s}}\left(\mu \mathrm{mol} \mathrm{CO}_{2} / \mathrm{mmol}\right.$ $\mathrm{H}_{2} \mathrm{O}$ ). Later, $A_{-} C_{i}$ curves were constructed on selected populations representing East (NBN, NBS) and West (CLK, MJW, WAK) using the methodology described by Soolanayakanahally et al. (2009). The maximum carboxylation rate allowed by Rubisco ( $\left.V_{\mathrm{cmax}}\right)$, rate of photosynthetic electron transport $(J)$, triose phosphate utilization (TPU) and internal conductance $\left(g_{\mathrm{m}}, \mathrm{mol} \mathrm{CO}_{2}\right.$ $\mathrm{m}^{-2} \mathrm{~s}^{-1}$ ) were estimated by fitting the $A_{-} C_{i}$ curve data to the model of Sharkey et al. (2007).

Following gas exchange measurements, chlorophyll content index (CCI) was measured on three fully expanded leaves per plant using an Opti-Sciences CCM-200 meter (Hudson, NH, USA) and averaged for statistical analyses. Two leaf discs were sampled using a hand held paper punch exactly from the same leaf used for gas exchange, and oven dried at $50^{\circ} \mathrm{C}$ for $72 \mathrm{~h}$ for recording leaf mass per unit area (LMA, $\mathrm{mg} \mathrm{mm}^{-2}$ ). The stem wood was collected in November 2014 at $15 \mathrm{~cm}$ above ground after recording non-coppiced biomass. Later, these leaf discs and stem wood samples were used to analyze leaf and wood carbon $(\mathrm{C})$ and nitrogen $(\mathrm{N})$ content and stable isotopes ratios $\left(\delta^{13} \mathrm{C}\right.$ and $\delta^{15} \mathrm{~N} ; \%$ ) at the UC Davis Stable Isotope Facility (Davis, CA, USA). All $\delta^{13} \mathrm{C}$ values were converted to $\Delta^{13} \mathrm{C}$ using Farquhar et al. (1989) equation with isotopic composition of the air to PeeDee Belemnite of $-8.3 \%$. Leaf $\mathrm{C}$ to $\mathrm{N}$ ratio $(\mathrm{C}: \mathrm{N} ; \mathrm{mg} / \mathrm{mg})$ and photosynthetic nitrogen-use efficiency (PNUE; $\mu \mathrm{mol} \mathrm{CO}_{2} \mathrm{~g}^{-1} \mathrm{~N} \mathrm{~s}^{-1}$ ) were calculated from these values. Stomatal density (number of stomata per unit of leaf area, $\mathrm{mm}^{-2}$ ) measurement samples 
were prepared by applying a thin coat of clear nail polish on the adaxial and abaxial surfaces of fully expanded leaves (Gornall and Guy 2007). The dried impressions were stripped from leaves and mounted onto clear microscopic slides for observation. The slides were viewed under Zeiss phase contrast microscope (Axio Lab A.1, Toronto, ON, Canada) and stomata were counted under 20x magnification. The final stomatal count was averaged from three randomly selected field views from one impression. The stomatal pore length $(\mu \mathrm{m})$ was measured on a subset of populations based on density ranks representing East (high stomatal density: PEI, NSW, QUE, NBS) and West (low stomatal density: MDN, DRU, KEN, IHD). Five genotypes from each population $(N=40)$ were randomly chosen to determine pore length on 5 stoma per genotype $(N$ $=200)$. Later, maximum stomatal conductance to $\mathrm{CO}_{2}\left(g_{\mathrm{c}(\max )}, \mathrm{mol} \mathrm{m}^{-2} \mathrm{~s}^{-1}\right)$ was estimated using a modified version of the Franks et al. (2012) equation.

The Climate Normals (1981-2010) of closest stations were obtained for all populations from Environment Canada (www.climate.weatheroffice.ec.gc.ca/climate_normals/index_e.html). Climate variables included frost free days (FFDs, days), mean annual precipitation (MAP, mm), mean summer temperature beginning from May to September $\left(\mathrm{MST},{ }^{\circ} \mathrm{C}\right)$ and degree days above $5^{\circ} \mathrm{C}\left(\mathrm{DD}>5,{ }^{\circ} \mathrm{C}\right)$. The FFD was calculated based on the number of days where minimum day temperature was above $0^{\circ} \mathrm{C}$, a proxy for growing season length at each location (Table 1).

\section{Statistical analysis}

All statistical analyses were performed using $\mathrm{R}$ studio statistical software (0.99.484 for Windows). Wherever possible the data from growth phenology traits were calculated from pooled data across 2013 and 2014. Analysis of variance (ANOVA) and correlation analysis for traits were performed to estimate the functional trait diversity and relationship among the populations used in the study. Broad-sense heritability $\left(H^{2}\right)$ estimates of traits were calculated as a ratio of genetic variability $\left(\sigma_{\mathrm{g}}^{2}\right)$ to phenotypic variability $\left(\sigma_{\mathrm{g}}^{2}+\sigma_{\mathrm{e}}^{2}\right) \rightarrow\left[H^{2}=\sigma_{\mathrm{g}}^{2} /\left(\sigma_{\mathrm{g}}^{2}+\sigma_{\mathrm{e}}^{2}\right)\right]$. Variance components were estimated based on ANOVA, where $\sigma_{\mathrm{e}}^{2}=\mathrm{M}_{\mathrm{e}}$ and $\sigma_{\mathrm{g}}^{2}=\left(\mathrm{M}_{\mathrm{g}}-\mathrm{M}_{\mathrm{e}}\right) / \mathrm{b}$ [ $\mathrm{M}_{\mathrm{e}}$; mean square of error, $\mathrm{M}_{\mathrm{g}}$; mean square of genotypes and $\mathrm{b}$; number of replications]. Pearson's correlation was performed to estimate correlation coefficients $(r)$ on all 338 genotypes among morpho-physiological traits and geo-climatic variables. Significant correlations between traits were expressed after Bonferroni correction $(P<0.001)$. 


\section{RESULTS}

327

The major aim of this study was to evaluate the extent of intraspecific variation in growth physiology and seasonal phenology of S. eriocephala; hence, genotypes were selected to be representative of a broad range of latitudes and longitudes. The geographical range spanned $15^{\circ}$ in latitude and $52^{\circ}$ in longitude, with elevation ranging from 4 to $800 \mathrm{~m}$ (Table 1). In general, the species range for $S$. eriocephala is at higher latitudes in the west, causing similar associations with longitude and elevation across Canada (Fig. 1). The average number of frost free days (a proxy for growing season length) ranged from 151 to 210 days with precipitation increasing from West $(316 \mathrm{~mm})$ to East $(1709 \mathrm{~mm})$. Growing degree days $\left(\mathrm{DD}>5{ }^{\circ} \mathrm{C}\right)$ were 60 units higher for eastern genotypes. A total of 25 traits related to ecophysiology, phenology and biomass were measured in 338 genotypes sourced from 34 populations.

\section{Phenotypic trait variations in S. eriocephala}

All measured traits showed a wide range of variation between genotypes and among populations

(Table 2). Photosynthetic assimilation rates $(A)$ ranged from 9.1 to $23.7 \mu \mathrm{mol} \mathrm{CO}_{2} \mathrm{~m}^{-2} \mathrm{~s}^{-1}$, with intrinsic water-use efficiency $\left(W U E_{\mathrm{i}}\right)$ fluctuating between $19.5-128.7 \mu \mathrm{mol} \mathrm{CO}_{2} / \mathrm{mmol} \mathrm{H}_{2} \mathrm{O}$. Both LMA and stomatal density displayed large variations among genotypes. Overall, leaf $\mathrm{N}$ and leaf $\mathrm{C}: \mathrm{N}$ ratios were higher than wood, with CCI ranging from 6.5 to 22.2 units. The carbon isotopic discrimination $\left(\Delta^{13} \mathrm{C}\right)$ for leaf and wood ranged from 16.8 to $23.1 \%$. While, the nitrogen isotopic discrimination $\left(\delta^{15} \mathrm{~N}\right)$ ranged between 3.4 to $21.2 \%$ o in leaf and wood tissues. Spring bud flush occurred within a week's time, whereas, leaf senescence spanned over 80 days. At our common garden location, the green cover duration ranged from 98 days to 166 days

\section{Correlation between geo-climatic and phenotypic variables}

351 Pearson correlation coefficients $(r)$ between geo-climatic parameters and phenotypic traits for all

352338 S. eriocephala genotypes are shown in Table 3 . It is evident that both $A$ and $g_{\mathrm{s}}$ increased 353 with increase in latitude (LAT), longitude (LON), elevation (ELV) and MSP. Conversely, both 354 traits were negatively correlated with FFD and MAP. WUE $E_{\mathrm{i}}$ among genotypes increased with 
increase in FFD and MAP. LMA increased with increase in LAT and LON implying that the leaves got thicker at high latitudes. While, stomatal density followed opposite trend. Both CCI and leaf $\mathrm{N}$ increased with increase in LAT, LON and ELV and decreased with increase in FFD and MAP. $\delta^{15} \mathrm{~N}_{\text {leaf }}$ and $\delta^{15} \mathrm{~N}_{\text {wood }}$ paralleled above trends. PNUE, wood $\mathrm{N}, \Delta^{13} \mathrm{C}_{\text {leaf }}$ and $\Delta{ }^{13} \mathrm{C}_{\text {wood }}$ were not significantly affected by any geo-climatic variables. The relationships between LAT and resource use-efficiencies [water $\left(\Delta^{13} \mathrm{C}\right)$ and nitrogen $\left(\delta^{15} \mathrm{~N}\right)$ ] are plotted in Fig. 4A and 4B, respectively. The $\delta^{15} \mathrm{~N}$ values of both leaf and wood increased significantly with increase in LAT (Fig. 4B). The DD $>5^{\circ} \mathrm{C}$ did not have any significant influence either on gas exchange or phenology traits.

Spring phenology (bud flush and leaf emergence) did not correlate with any geo-climatic variables. However, autumn events (leaf senescence, leaf drop, GCD) were negatively correlated with LAT, LON and ELV and positively correlated with FFD and MAP. The Melampsora rust incidence among the populations followed the reverse trend. Rust onset and its severity were positively correlated with LAT, LON, ELV and MST, but were negatively correlated with FFD and MAP. Genotypes from higher latitudes made significant height gains displaying positive correlations with LAT and LON. Non-coppiced single stem biomass was negatively correlated with FFD and MAP in our common garden.

\section{Correlation among phenotypic variables}

Traits related to ecophysiology, phenology and biomass were analyzed for functional intercorrelations and shown in a heat map (Fig. 3). The ecophysiological traits analyzed among the populations showed significantly stronger positive or negative correlations among each other. Photosynthetic assimilation rate $(A)$, stomatal conductance $\left(g_{\mathrm{s}}\right)$, transpiration rate $(E)$, PNUE and $C_{\mathrm{i}} / C_{\mathrm{a}}$ were largely positive correlated to each other. The $W U E_{\mathrm{i}}$ was negatively correlated with $A$, $g_{\mathrm{s}}, E$ and $C_{\mathrm{i}} / C_{\mathrm{a}}$. LMA is negatively correlated with PNUE and positively with Leaf $\mathrm{N}, \delta^{15} \mathrm{~N}_{\text {leaf }}$, $\delta^{15} \mathrm{~N}_{\text {wood }}$ and height. Stomatal density was positively correlated with autumn phenology and negatively with $A$, rust and height gain. CCI and leaf $\mathrm{N}$ are positively correlated with $A$ and rust. $\Delta^{13} \mathrm{C}_{\text {leaf }}$ was correlated positively with PNUE and negatively with leaf $\mathrm{N} . \delta^{15} \mathrm{~N}_{\text {leaf }}$ and $\delta^{15} \mathrm{~N}_{\text {wood }}$ were positively correlated to each other and also with $A$. 


\section{5}

Most of the phenological traits were negatively correlated to ecophysiological traits (Fig.3). Bud flush was not significantly correlated to either $g_{\mathrm{s}}$ or PNUE. A similar trend was observed between leaf unfolding and $\delta^{15} \mathrm{~N}_{\text {leaf }}$ and between rust incidences. Leaf senescence, GCD and leaf drop were negatively correlated to $A, g_{\mathrm{s}}, E, \mathrm{CCI}$, leaf $\mathrm{N}, \delta^{15} \mathrm{~N}_{\text {leaf }}, \delta^{15} \mathrm{~N}_{\text {wood }}$ and rust incidence, and positively correlated to $W U E_{\mathrm{i}}$ and stomatal density. The correlation between leaf senescence, GCD and leaf drop was significantly positive $(r=0.75)$. Height and biomass showed less correlation with ecophysiological and phenology traits. There was no significant correlation between biomass and $\Delta^{13} \mathrm{C}_{\text {wood }}$ and $\delta^{15} \mathrm{~N}_{\text {wood. }}$

\section{Stomatal pore length and $g_{\mathrm{m}}$}

Based on the stomatal density ranking we measured stomatal pore length in eight populations representative of either ends of the range. Populations originating from Eastern Canada (low latitudes) had high stomatal density (124 $\pm 3.08 \mathrm{SE}$ ) per unit leaf area with a smaller pore length $(11.168 \mu \mathrm{m})$. In contrast, populations originating from Western Canada (high latitudes) had fewer stomata $(68 \pm 2.19 \mathrm{SE})$ per unit leaf area but a longer pore length $(16.864 \mu \mathrm{m})$. The significant differences in stomatal pore length and stomatal density are shown in Fig. 5A-5B $(P$ $<0.001$ ). We also observed significant differences in $g_{\text {s }}$ (Fig. 5C, $P<0$. 001) among eight populations, however, the maximum diffusive conductance to $\mathrm{CO}_{2}\left(g_{\mathrm{c}(\max )}\right)$ as determined by stomatal density and pore length reached physiological optima at either ends of the species range to achieve maximum carbon gain (Fig. 5D, $P=0.09$ ).

Following gas exchange measurements, a total of ten $\mathrm{CO}_{2}$ response curves were constructed and data analyzed using $A_{-} C_{i}$ curve fitting model. The corresponding estimates of $g_{\mathrm{m}}, V_{\mathrm{cmax}}, J$ and TPU were plotted in Fig. 6A-6D for three populations from the west (CLK, MJW, WAK) and two populations from the east (NBN, NBS). The western genotypes had higher $g_{\mathrm{m}}(0.288 v s$. $\left.0.198 ; \mathrm{mol} \mathrm{CO}_{2} \mathrm{~m}^{-2} \mathrm{~s}^{-1}\right), V_{\text {cmax }}(107 v s .93), J(146 v s .114)$ and TPU (10.52 vs. 8.48) values than the eastern genotypes. The variance between their mean values shows the difference in magnitudes of these values.

\section{Broad-sense heritability and rust infestation}


416

417

418

419

420

421

422

423

424

425

426

427

428

429

430

431

432

433

434

435

436

437

438

439

440

441

442

443

444

445

446

Heritability estimates $\left(H^{2}\right)$ estimates were calculated for seasonal phenology and biomass related traits. The $H^{2}$ estimates ranged from 0.62 to 0.95 among the traits (Table 3). Bud flush, leaf emergence, leaf senescence and leaf drop had heritability estimates of 0.72, 0.77, 0.62 and 0.78, respectively. Height gain had higher heritability estimate (0.95) than biomass (0.88). A latitudinal cline with Melampsora rust incidence scores are shown in Fig. 7.

\section{DISCUSSION}

This is the first comprehensive study on a substantial number of native populations that originated from varying latitudes and longitudes in S. eriocephala. The above results emphasize the importance of considering key ecophysiological and phenological traits while studying local adaptation among willow populations of divergent origin. Besides, these physiological mechanisms are discussed in the light of convergent evolution among the members of the genus Salicaceae - a sympatric adaptive phenotype to very similar climate and photoperiod.

\section{Adaptive variations in photosynthesis}

Planted into a common environment (indoor greenhouse and/or outdoor common garden), observed functional traits differences among populations originating along an environmental gradient can be influenced by past evolutionary history resulting in adaptive genetic variations. In our study, photosynthetic assimilation rate $(A)$ increased with increase in latitude when measured during free growth in S. eriocephala genotypes. This is an agreement with the previous findings in North American Populus species which occupy similar climates (Gornall and Guy 2007, Soolanayakanahally et al. 2009, McKown et al. 2014a, Kaluthota et al. 2015). Collectively, these studies hypothesised that the observed patterns of higher $A$ among high latitude genotypes represent true adaptive variation in response to growing season length. Whereby, genotypes from shorter growing seasons possess inherently higher $A$ compared to the genotypes from longer growing seasons. Again, higher $A$ in $S$. eriocephala is associated with higher $g_{\mathrm{s}}$, LMA, CCI and Leaf N (Soolanayakanahally et al. 2009, McKown et al. 2014a, Kaluthota et al. 2015), resulting in greater height gain among high latitude genotypes. A similar height gain was observed among high latitude $P$. balsamifera populations when photoperiodic constraints were removed by growing under extended daylength (Soolanayakanahally et al. 
447 448

449

450

451

452

453

454

455

456

457

458

459

460

461

462

463

464

465

466

467

468

469

470

471

472

473

474

475

476

2009). On the other hand, when daylength was limiting, height rankings reversed leading to alterations in root:shoot ratios (Soolanayakanahally et al. 2013).

Significant increases in $A$ were found in other deciduous tree species (Benowicz et al. 2000, Soolanayakanahally et al. 2015) and evergreen conifers (Picea glauca [Moench] Voss, Benomar et al. 2015) sourced along a north-south gradient with varying growing season length. Such adaptation to growing season length in photosynthetic assimilation rates can be generalized along elevational gradients as well (Oleksyn et al.1998).

Plant species occupying large geographic areas provide cues about adaptation mechanisms to various environmental conditions (Brosché et al. 2010). Leaf stomata regulate $\mathrm{CO}_{2}$ uptake and $\mathrm{H}_{2} \mathrm{O}$ use during photosynthesis and transpiration, respectively. Our S. eriocephala genotypes were entirely hypostomatous and stomatal density is negatively correlated with latitude and longitude (while, $g_{\mathrm{s}}$ is positively correlated with latitude and longitude). Stomatal density and pore length were negatively correlated with each other, one compensating for the other. Wang et al. (2015) studied latitudinal variation in stomatal traits across 760 species to highlight a strong negative relationship between stomatal density and stomatal length governing physiological adaptation to the environment. In their study, the plant species at low latitudes had higher stomatal density and reduced stomatal length than those distributed at high latitudes.

Among plant groups, the maximum diffusive conductance to $\mathrm{CO}_{2}\left(g_{\mathrm{c}(\max )}\right)$ and water vapor is ultimately determined by stomatal density and pore length which may serve as a physiological framework to optimize leaf carbon/water balance (Franks et al. 2012). These long-term evolutionary scale adjustments in stomatal density and pore length in response to environmental conditions have facilitated S. eriocephala to expand into newer habitats leading to local adaptation. As the epidermal stomatal design features evolved 400-million years before present, the observed negative relationship between stomatal density and pore length suggests a widespread highly conversed genetic basis among vascular plants (Franks and Beerling 2009). So, we postulate that larger pore length with fewer number of stomata per unit leaf area certainly contribute to high $g_{\mathrm{s}}$, in turn higher $A$ among high latitude genotypes - a necessary "energy 
477

478

479

480

481

482

483

484

485

486

487

488

489

490

491

492

493

494

495

496

497

498

499

500

501

502

503

504

505

506

507

constraint trade-off' to maximise returns in $g_{\mathrm{s}}$ and $A$ for a given investment in stomata construction costs under global leaf economics spectrum.

The observed difference in $A$ is determined by $g_{\mathrm{s}}$ resulting from a combination of stomatal density and pore length; however, we must not discount the role of $g_{\mathrm{m}}$ as well. The physiological mechanisms involved in higher $A$ have been the subject of extensive investigation in the recent past (Muir et al. 2013, Cano et al. 2013, Buckley and Warren 2014, Barbour et al. 2015). Such an examination of underlying physiological mechanisms in $S$. eriocephala are none and this study provide a first glimpse into naturally occurring variability in $g_{\mathrm{m}}$. Even though our results on a small subset were not significant for $A-C_{\mathrm{i}}$ curve fitting estimates, overall the observed trends points towards higher $g_{\mathrm{m}}$ at high latitudes. Previously, Soolanayakanahally et al. (2009) reported an adaptive role of $g_{\mathrm{m}}$ in enhancing $\mathrm{CO}_{2}$ uptake efficiency and photosynthetic capacity among $P$. balsamifera trees adapted to short growing season. This enhanced $g_{\mathrm{m}}$ is linked to increased palisade surface area exposed to intercellular air space for $\mathrm{CO}_{2}$ diffusion (Milla-Moreno et al. 2016), accounting for the positive association between LMA and $g_{\mathrm{m}}$ (Ryan 2015). Such positive and negative association between LMA (thicker or denser leaf tissue, or both) and $g_{\mathrm{m}}$ is reported in other plant species as well. In addition, Théroux Rancourt et al. (2015) highlighted the importance of mesophyll-to-stomatal $\left(g_{\mathrm{m}} / g_{\mathrm{s}}\right)$ ratios while breeding for dry climates within Salicaceae species. Finally, we provide evidences for higher $A$ among high latitude $S$. eriocephala genotypes ably supported by higher $g_{\mathrm{s}}$, larger stomatal pore length and enhanced $g_{\mathrm{m}}$.

\section{Clines in resource acquisition}

Establishing the link between resource acquisition efficiencies and ecophysiological traits among the populations is essential to further understand their adaptive behaviours. Díaz et al. (2016) mapped global trait spectrum in 46,085 vascular plant species to reflect "acquisitive $v s$. conservative" trade-offs between LMA and leaf $\mathrm{N}$ in constructing photosynthetic leaf. In their study, across biomes and plant species, cheaply constructed leaves with short lifespan were nitrogen-rich with low-LMA (acquisitive leaves), while leaves with long lifespan were nitrogenpoor with high-LMA (conservative leaves). Conversely, we found opposite patterns in LMA within S. eriocephala collection that occupies temperate-boreal climates. Whereby, shorter lifespan leaves had higher LMA (nitrogen-rich), while longer lifespan leaves had lower LMA 
508

509

510

511

512

513

514

515

516

517

518

519

520

521

522

523

524

525

526

527

528

529

530

531

532

533

534

535

536

537

538

(nitrogen-poor). Similar "within species" patterns in LMA was also observed in P. balsamifera that encompass vast geographic ranges (Soolanayakanahally et al. 2009). Even though no significant association exists between LMA and ELV in our study, others found that LMA increases with ELV as well (Poorter et al. 2009).

Higher leaf $\mathrm{N}$ contents are associated with higher $A$ as large amounts of inorganic nitrogen $(\sim 75 \%)$ are present in the chloroplast (Evans and Seemann 1989). We observed a strong positive correlation between $A$, leaf $\mathrm{N}$ and LMA. At the same time, PNUE is negatively associated with leaf $\mathrm{N}$ and LMA. So possible explanations for high LMA to have lower PNUE could be due to variation in nitrogen allocation between photosynthetic vs. non-photosynthetic structures, and also as a result of differential allocation of photosynthetic $\mathrm{N}$ between light harvesting complexes, electron transport and $\mathrm{CO}_{2}$ fixation (Field and Mooney 1986). It seems that low latitude $S$. eriocephala genotypes invest more $\mathrm{N}$ towards foliar structures to withstand biotic and abiotic stressors, while fast-growing high latitude genotypes allocates more $\mathrm{N}$ to photosynthetic apparatus. Previously, Weih and Rönnberg-Wastljung (2007) concluded a positive association between leaf $\mathrm{N}$ and photosynthetic capacity in Salix genotypes.

$W U E_{\mathrm{i}}$ decreases as $C_{\mathrm{i}} / C_{\mathrm{a}}$ increases, suggesting a potential intrinsic trade-off between $W U E_{\mathrm{i}}$ and PNUE (Field et al. 1983). Both these resource use-efficiency indicators of gas exchange ( $W U E_{\mathrm{i}}$ and PNUE) mutually depend on $g_{\mathrm{s}}$, and are influenced by leaf-to-air temperature, light and available soil moisture. Unlike $\mathrm{H}_{2} \mathrm{O}, \mathrm{CO}_{2}$ faces further resistance in diffusion from intercellular spaces to the site of carbon fixation $\left(g_{\mathrm{m}}\right)$. But, when $P$. balsamifera was grown without resource limitation, $W U E_{\mathrm{i}}$ increased with increase in latitude (Soolanayakanahally et al. 2009). We recognise the limitation in inferring $W U E_{\mathrm{i}}$ based on a single common garden. Turner et al. (2010) were able to differentiate the genetic and plastic responses in $\Delta^{13} \mathrm{C}$ in Eucalyptus species by taking into account the results from two common gardens.

A negative relationship between $W U E_{\mathrm{i}}$ and $\Delta^{13} \mathrm{C}$ has been extensively reported in many plants and is genetically determined (Farquhar et al. 1989). $\Delta{ }^{13} \mathrm{C}$ values reflect on how plant species adjust their gas exchange metabolism, interplay of $\mathrm{CO}_{2}$ and $\mathrm{H}_{2} \mathrm{O}$ acquisition and use, and adaptation patterns to different environments (Dawson et al. 2002). McKown et al. (2014a) 
539

540

541

542

543

544

545

546

547

548

549

550

551

552

553

554

555

556

557

558

559

560

561

562

563

564

565

566

567

568

569

reported a $6.6 \%$ range in $\Delta^{13} \mathrm{C}$ values among 461 natural accessions of $P$. trichocarpa. Often the variations in $W U E_{\mathrm{i}}$ and $\Delta^{13} \mathrm{C}$ are associated with the variations in photosynthetic capacity of the populations (Pointeau and Guy 2014). In this study, even though no linkages were observed between $\Delta^{13} \mathrm{C}$ and geo-climatic variables, we found trait associations between $\Delta^{13} \mathrm{C}$, PNUE and leaf $\mathrm{N}$. Such variations in $\Delta^{13} \mathrm{C}$ and their relative role in photosynthetic capacity and adaptation have been studied in many trees (Anderson et al. 1996; Monclus et al. 2005).

Intraspecific variation in nitrogen uptake and assimilation may differ among plant populations adapted to temperate $\left(\mathrm{NO}_{3}\right.$ dominant soils) and boreal $\left(\mathrm{NH}_{4}\right.$ dominant soils) climates. Soil derived $\mathrm{NO}_{3}$ nitrogen is assimilated by the nitrate reductase (NR) and nitrite reductase (NiR) pathway, producing $\mathrm{NH}_{4}$. Subsequently, soil derived $\mathrm{NH}_{4}$ along with $\mathrm{NO}_{3}$ derived $\mathrm{NH}_{4}$ is assimilated via the glutamine synthetase (GS) and ferredoxin glutamate synthase (fd-GOGAT) pathway resulting in $\delta^{15} \mathrm{~N}$ variations of plant tissues (Lopes and Araus 2006). Hence, natural abundance of $\delta^{15} \mathrm{~N}$ in a plant provides an insight into the causal relationships between uptake, assimilation and allocation of nitrogen (Kalcsits and Guy, 2013). If $\mathrm{NO}_{3}$ is partially assimilated in roots than shoots are enriched in $\delta^{15} \mathrm{~N}$ or if wholly assimilated in roots or shoots than shoots are not enriched in $\delta^{15} \mathrm{~N}$. We observed between 2 and $4 \%$ within plant variation (leaf $v s$. wood), and this could be due to partial assimilation of source nitrogen (particularly, $\mathrm{NO}_{3}$ ) in the roots, resulting in isotopic differences between tissue types (Evans et al. 1996). The observed latitudinal clines in $\delta^{15} \mathrm{~N}$ imply that there is an adaptive genetic variation in assimilation of $\mathrm{NO}_{3}$ nitrogen between roots and shoots in S. eriocephala.

\section{Geographic variation in Salix seasonality}

Functional traits that explain ecophysiological capacities are constantly modified during the growing season as a result of growth cessation and bud set (McKown et al. 2013). For instance, bud set has high heritability across multiple years $\left(H^{2}=0.739\right)$, whereas vegetative traits such as, leaf mass per unit area $\left(H^{2}=0.810\right.$ spring; $H^{2}=0.150$ post bud set $)$ is more plastic within a given season (McKown et al. 2014a). A number of common garden studies under single photoperiodic regime suggest daylength sensitivity in bud phenology to have a genetic basis (Ingvarsson et al. 2006, McKown et al. 2014a). For most deciduous trees, having met the chilling needs (endo-dormancy), the onset of spring bud flush marks the shift from a dormant, restive 
stage (eco-dormancy) to an active growth stage upon accumulation of necessary heat sums under favourable environmental conditions (Worrall 1993).

Spring leaf emergence has been shown to have advanced over the past century with a steady lengthening of growing seasons (McMahon et al. 2010) leading to increased carbon fixation by terrestrial plants (Peñuelas et al. 2009). On the other hand, this increase in carbon sequestration is partially offset by enhanced rates of respiration (Piao et al. 2008). Temperature driven spring green-up often displays lower broad-sense heritability $\left(H^{2}=0.43\right.$ to 0.68 , Tsarouhas et al. 2003) as temperatures fluctuate a lot from year-to-year. Previous common garden studies have reported a narrow range for bud flush ( 1-3 weeks) among intraspecific populations that display a latitudinal cline (Acer saccharum Marsh., Kriebel 1957; Betula alleghaniensis, Clausen and Garrett 1969; P. balsamifera and P. tremula L., Soolanayakanahally et al. 2013, 2015; P. trichocarpa, McKown et al. 2014a), but higher spring temperature can shorten the duration for bud flush. So, under common garden environments, trees from low latitudes often display later bud flush due to higher chilling and heat unit needs than the trees from high latitudes (Hannerz et al. 2003). Weih (2009) study emphasis spring leaf emergence and leaf abscission events' being critical for biomass accumulation by Salix species and it is important to determine the impacts of future spring temperature change on the timing of bud flush at a given latitude.

While Populus has been a focus of extensive works in understanding the molecular mechanisms of autumn phenology primarily cued by photoperiod (Ingvarsson et al. 2006, Keller et al. 2011) such an understanding is lacking for Salix (Hallingbäck et al. 2015). The seasonal variation in photoperiod is consistent from year-to-year and is a reliable cue for onset of bud set, leaf senescence and induction of dormancy than temperature which is far less predictable and shows seasonal fluctuations (Barr et al. 2004). Our observed latitudinal cline in the onset of senescence and leaf drop is consistent with our a priori expectations. As willow plants attain competency to respond to photoperiod by mid-summer, they would have to wait for the critical daylength to induce autumn phenological events (Soolanayakanahally et al. 2013), with high latitude genotypes ceasing growth under longer critical daylength than the trees from low latitude (Pauley and Perry 1954, Howe et al. 1995). 
601

602

603

604

605

606

607

608

609

610

611

612

613

614

615

616

617

618

619

620

621

622

623

624

625

626

627

628

629

630

631

632

At high latitudes, greater susceptibility to insect and disease is largely explained by evolution of plant defenses which display latitudinal clines (Anstett et al. 2015). As observed in this study, geographic regions that experience low Melampsora rust occurrence, natural resistance could be negatively selected in the absence of biotic stressors. In addition, larger stomatal pore length among high-latitude $S$. eriocephala genotypes might provide greater surface area for Melampsora rust spores to penetrate and colonise a given leaf surface area compared to lowlatitude genotypes. Our results find support for the hypothesis "carbon gain and disease resistance trade-offs" by McKown et al. (2014b), the notion that fast growth might have negative fitness with disease resistance. In addition, an inherent resistance to Melampsora rust is metabolically costly with substantial increase in certain classes of metabolites, particularly, tannins.

\subsection{Adaptive phenotypic trait convergence within Salicaceae}

In the Northern Hemisphere the members of Salicaceae (P. balsamifera and S. eriocephala) are sympatric species with overlapping natural ranges across north temperate-boreal climates (Hosie RC 1979, Dorn 1970). Both are restricted to moist and nutrient rich sites, exhibit indeterminate growth, and have a much wider north-south range. In general, parallel evolutionary selection pressures produce functionally convergent phenotypic traits in related taxa. Broadly, we hypothesised that the patterns in form and function convergence on a similar adaptive phenotype among Populus and Salix species in spite their long divergence ( 65 million years).

In a greenhouse study, without any resource limitations $P$. balsamifera populations displayed latitudinal gradients in photosynthesis $(A)$, whereby higher $A$ was ably supported by enhanced $g_{\mathrm{m}}$ and leaf $\mathrm{N}$ at high latitudes (Soolanayakanahally et al. 2009). Similar mechanism in $S$. eriocephala was observed in an outdoor common garden, whereby higher $A$ in genotypes from high latitudes is partly mediated by higher $g_{\mathrm{m}}$ and $g_{\mathrm{s}}$ (mediated by larger stomatal pore length rather than higher density). These two studies collectively demonstrate a very strong correlation between $A$ and latitude of origins and thus suggest that the possibility of a convergent adaptive phenotypic trait selection to compensate for short growing seasons. In addition, both species were hypostomatous with stomatal density displaying a strong negative association with latitude of origin. Unlike greenhouse grown P. balsamifera, $g_{\text {s }}$ was positively correlated with latitude of origin in S. eriocephala. In addition, Leaf N, LMA and CCI were positively associated with 
633

634

635

636

637

638

639

640

641

642

643

644

645

646

647

648

649

650

651

652

653

654

655

656

657

658

659

660

661

662

each other contributing to greater $A$ at high latitudes in both species. Four independent common garden studies along a latitudinal gradient by the same group (Soolanayakanahally et al. 2009, 2015, McKown et al. 2014a, present study) and an additional study by Kaluthota et al. (2015) showed that genetic divergence in Salicaceae members largely explains the variation observed in functionally important leaf traits $-A$, LMA, Leaf N.

Further, both species display a strong latitudinal cline in autumn phenology (leaf senescence, green cover period, leaf drop) resulting from photoperiodic adaptation (Soolanayakanahally et al. 2013). Overall, our findings in S. eriocephala and P. balsamifera lend support to the hypothesis that natural selective pressures enacted along similar environmental gradients led to phenotypic trait convergence in sympatric Salicaceae members.

\section{CONCLUSION}

Our common garden results speak to the paramount role of adaptive trade-offs along latitudinal gradients, suggesting that certain trait combinations have been favoured by natural selection, leading to a locally adapted phenotype. First, we found multiple evidences for an enhanced photosynthetic assimilation rate $(A)$ at high latitudes ably supported by stomatal traits (increased $g_{\mathrm{s}}$, and larger stomatal pore length) and a greater $g_{\mathrm{m}}$ which all coevolved along geo-climatic gradients. In addition, higher $A$ at high latitudes results from greater LMA with higher leaf $\mathrm{N}$ concentrations. Taken together, our results highlight latitudinal clines in $A$ as an adaptation to growing season length. Second, we observed least variations in water use-efficiency as determined by $\Delta^{13} \mathrm{C}$ values among genotypes from different latitudes with varying precipitation patterns. Observed latitudinal cline in $\delta^{15} \mathrm{~N}$ values suggests that $\mathrm{NO}_{3}$ nitrogen is partially assimilated in the roots leading to enrichment of stem wood tissue. Last, a strong photoperiodic adaption was observed in autumn phenology traits accounting for high heritability that could be exploited in willow improvement program for biomass and environmental applications. Overall, an adaptive negative relationship between stomatal density and pore length is optimised to achieve maximum leaf diffusive conductance to $\mathrm{CO}_{2}$ within the physiological framework of carbon/water balance across a range of a latitudes and climates. 


\section{AUTHOR CONTRIBUTION}

664 A.S.K.S. participated in data analysis and interpretation and drafted the manuscript. R.Y.S.

665 conceived the study, performed gas exchange measurements, participated in analysis and

666 interpretation, and edited the manuscript. R.D.G. interpreted the stable isotope results and

667 complemented the writing. The authors declare that the research was conducted in the absence of

668 any commercial or financial relationships that could be construed as a potential conflict of

669 interest.

670

671

672

673

674

675

676

677

678

679

680

681

682

683

684

685

686

687

688

689

690

691

692

693

694

\section{ACKNOWLEDGMENTS}

The efforts of Don Reynard and Chris Stefner in establishing the willow common garden is wholly appreciated. We thank Hamid Naeem for monitoring phenology over two seasons. This work was funded to R.Y.S. by the Agriculture and Agri-Food Canada (LOI 1268) and by the Natural Sciences and Engineering Research Council of Canada (NSERC) Discovery Grants Program to R.D.G. A.S.K.S. is a NSERC Visiting Fellow at AAFC. The authors express thanks to George Argus for assistance with willow specimen identification. 


\section{REFERENCES}

Aitken SN, Whitlock MC (2013) Assisted gene flow to facilitate local adaptation to climate change. Annu Rev Ecol Evol Syst 44: 367-388

Alberto FJ, Aitken SN, Alía R, González-Martínez SC, Hänninen H, Kremer A, Lefèvre F, Lenormand T, Yeaman S, Whetten R, Savolainen O (2013) Potential for evolutionary responses to climate change - evidence from tree populations. Glob Chang Biol 19: $1645-1661$

Anderson JE, Williams J, Kriedemann PE, Austin MP, Farquhar GD (1996) Correlations between carbon isotope discrimination and climate of native habitats for diverse eucalypt taxa growing in a common garden. Aust J Plant Physiol 23: 311-320

Anstett DN, Ahern JR, Glinos J, Nawar N, Salminen JP, Johnson MT (2015) Can genetically based clines in plant defence explain greater herbivory at higher latitudes? Ecol Lett 18: 1376-1386

Argus GW (2010) Salix L. In: Flora of North America Editorial Committee (ed), Flora of North America North of Mexico,Volume 7. Magnoliophyta: Salicaceae to Brassicaceae. Oxford University Press, Oxford, pp 23-162

Barbour MM, Bachmann S, Bansal U, Bariana H, Sharp P (2016) Genetic control of mesophyll conductance in common wheat. New Phytol 209: 461-465

Barr AG, Black TA, Hogg EH, Kljun N, Morgenstern K, Nesic Z (2004) Inter-annual variability in the leaf area index of a boreal aspen-hazelnut forest in relation to net ecosystem production. Agric For Meteorol 126: 237-255

Benomar L, Lamhamedi MS, Rainville A, Beaulieu J, Bousquet J, Margolis HA (2016) Genetic adaptation vs. ecophysiological plasticity of photosynthetic-related traits in young Picea glauca trees along a regional climatic gradient. Front Plant Sci 7: 48

Benomar L, Lamhamedi MS, Villeneuve I, Rainville A, Beaulieu J, Bousquet J, Margolis HA (2015) Fine-scale geographic variation in photosynthetic-related traits of Picea glauca seedlings indicates local adaptation to climate. Tree Physiol 35: 864-878

Benowicz A, Guy DR, El-Kassaby AY (2000) Geographic pattern of genetic variation in photosynthetic capacity and growth in two hardwood species from British Columbia. Oecologia 123: 168-174

Berlin S, Trybush SO, Fogelqvist J, Gyllenstrand N, Hallingbäck HR, Åhman I, Nordh NE, Shield I, Powers SJ, Weih M, Lagercrantz U, Rönnberg-Wästljung A-C, Karp A, Hanley SJ (2014) Genetic diversity, population structure and phenotypic variation in European Salix viminalis L. (Salicaceae). Tree Genet Genomes 10: 1595-1610

Bridgwater FE (1990) Shoot elongation patterns of loblolly pine families selected for contrasting growth potential. For Sci 36: 641-656

Broeckx LS, Fichot R, Verlinden MS, Ceulemans R (2014) Seasonal variations in photosynthesis, intrinsic water-use efficiency and stable isotope composition of poplar leaves in a short-rotation plantation. Tree Physiol 34: 701-715

Brosche M, Merilo E, Mayer F, Pechter P, Puzorjova I, Brader G, Kangasjarvi J, Kollist H (2010) Natural variation in ozone sensitivity among Arabidopsis thaliana accessions and its relation to stomatal conductance. Plant Cell Environ 33: 914-925

Buckley TN, Warren CR (2013) The role of mesophyll conductance in the economics of nitrogen and water use in photosynthesis. Photosynth Res 119: 77-88 
Cano FJ, SÁNchez-GÓMez D, RodríGuez-Calcerrada J, Warren CR, Gil L, Aranda I (2013) Effects of drought on mesophyll conductance and photosynthetic limitations at different tree canopy layers. Plant Cell Environ 36: 1961-1980

Chapin FS, Oechel WC (1983) Photosynthesis, respiration, and phosphate absorption by Carex aquatilis ecotypes along latitudinal and local environmental gradients. Ecology 64: 743751

Dawson TE, Mambelli S, Plamboeck AH, Templer PH, Tu KP (2002) Stable isotopes in plant ecology. Annu Rev Ecol Syst 33: 507-559

Díaz S, Kattge J, Cornelissen JHC, Wright IJ, Lavorel S, Dray S, Reu B, Kleyer M, Wirth C, Colin Prentice I, Garnier E, Bönisch G, Westoby M, Poorter H, Reich PB, Moles AT, Dickie J, Gillison AN, Zanne AE, Chave J, Joseph Wright S, Sheremet'ev SN, Jactel H, Baraloto C, Cerabolini B, Pierce S, Shipley B, Kirkup D, Casanoves F, Joswig JS, Günther A, Falczuk V, Rüger N, Mahecha MD, Gorné LD (2016) The global spectrum of plant form and function. Nature 529: 167-171

Dorn RD (1970) The willows of Montana. Herbarium, Department of Botany and Microbiology, Montana State Univ, Bozeman

Evans JR, Seemann JR (1989) The allocation of protein nitrogen in the photosynthetic apparatus: costs, consequences, and control. In WR Briggs, ed, Photosynthesis. Liss, New York, pp 183-205

Evans RD, Bloom AJ, Sukrapanna SS, Ehleringer JR (1996) Nitrogen isotope composition of tomato (Lycopersicon esculentum Mill. cv. T-5) grown under ammonium or nitrate nutrition. Plant Cell Environ 19: 1317-1323

Farquhar GD, Ehleringer JR, Hubick KT (1989) Carbon isotope discrimination and photosynthesis. Annu Rev Plant Phys Plant Mol Biol 40: 503-537

Field C, Merino J, Mooney HA (1983) Compromises between water-use efficiency and nitrogen-use efficiency in five species of California evergreens. Oecologia 60: 384-389

Field C, Mooney HA (1986) The photosynthesis-nitrogen relationship in wild plants. In TJ Givnish, ed, On the economy of plant form and function. Cambridge University Press, Cambridge, pp 25-55

Flexas J, Ribas-Carbo M, Hanson DT, Bota J, Otto B, Cifre J, McDowell N, Medrano H, Kaldenhoff R (2006) Tobacco aquaporin NtAQP1 is involved in mesophyll conductance to $\mathrm{CO} 2$ in vivo. Plant J 48: 427-439

Flood PJ, Harbinson J, Aarts MG (2011) Natural genetic variation in plant photosynthesis. Trends Plant Sci 16: 327-335

Fracheboud Y, Luquez V, Björkén L, Sjödin A, Tuominen H, Jansson S (2009) The control of autumn senescence in European aspen. Plant Physiol 149: 1982-1991

Franks PJ, Beerling DJ (2009) Maximum leaf conductance driven by CO2 effects on stomatal size and density over geologic time. PNAS 106: $10343-10347$

Franks PJ, Leitch IJ, Ruszala EM, Hetherington AM, Beerling DJ (2012) Physiological framework for adpatation of stomata to $\mathrm{CO}_{2}$ from glacial to future concentrations. Phil. Trans. R. Soc. B 367: 537-546

Friedman JM, Roelle JE, Cade BS (2011) Genetic and environmental influences on leaf phenology and cold hardiness of native and introduced riparian trees. Int $\mathbf{J}$ Biometeorol 55: $775-787$ 
Ghelardini L, Berlin S, Weih M, Lagercrantz U, Gyllenstrand N, Rönnberg-Wästljung AC (2014) Genetic architecture of spring and autumn phenology in Salix. BMC Plant Biol 14: $1-18$

Gornall JL, Guy RD (2007) Geographic variation in ecophysiological traits of black cottonwood (Populus trichocarpa). Can J Bot 85: 1202-1213

Gresset S, Westermeier P, Rademacher S, Ouzunova M, Presterl T, Westhoff P, Schon CC (2014) Stable carbon isotope discrimination is under genetic control in the C4 species maize with several genomic regions influencing trait expression. Plant Physiol 164: 131143

Guy RD, Holowachuk DL (2001) Population differences in stable carbon isotope ratio of Pinus contorta Dougl. ex Loud.: relationship to environment, climate of origin, and growth potential. Can J Bot 79: 274-283

Hallingbäck HR, Fogelqvist J, Powers SJ, Turrion-Gomez J, Rossiter R, Amey J, Martin T, Weih M, Gyllenstrand N, Karp A, Lagercrantz U, Hanley SJ, Berlin S, RönnbergWästljung A-C (2015) Association mapping in Salix viminalis L. (Salicaceae) identification of candidate genes associated with growth and phenology. GCB Bioenergy 8: $670-685$

Hannerz M, Ekberg I, Norell L (2002) Variation in chilling requirements for completing bud rest between provenances of Norway spruce. Silvae Genet 52: 161-168

Hodkinson ID (1999) Species response to global environmental change or why ecophysiological models are important: a reply to Davis et al. J A Ecol 68: 1259-1262

Hosie RC (1979) Native trees of Canada, Ed 8. Markham, ON: Fitzhenry and Whiteside, Ltd

Howe GT, Hackett WP, Furnier GR, Klevorn RE (1995) Photoperiodic responses of a northern and southern ecotype of black cottonwood. Physiol Plant 93: 695-708

Ingvarsson PK, Garcia MV, Hall D, Luquez V, Jansson S (2006) Clinal variation in phyB2, a candidate gene for day-length-induced growth cessation and bud set, across a latitudinal gradient in European aspen (Populus tremula). Genetics 172: 1845-1853

Kalcsits LA, Guy RD (2013) Whole-plant and organ-level nitrogen isotope discrimination indicates modification of partitioning of assimilation, fluxes and allocation of nitrogen in knockout lines of Arabidopsis thaliana. Physiol Plant 149: 249-259

Kalcsits LA, Guy RD (2016) Variation in fluxes estimated from nitrogen isotope discrimination correspond with independent measures of nitrogen flux in Populus balsamifera L. Plant Cell Environ 39: 310-319

Kaluthota S, Pearce DW, Evans LM, Letts MG, Whitham TG, Rood SB (2015) Higher photosynthetic capacity from higher latitude: foliar characteristics and gas exchange of southern, central and northern populations of Populus angustifolia. Tree Physiol 35: 936948

Keller SR, Levsen N, Ingvarsson PK, Olson MS, Tiffin P (2011) Local selection across a latitudinal gradient shapes nucleotide diversity in balsam poplar, Populus balsamifera L. Genetics 188: 941-952

Kohl DH, Shearer GB, Commoner B (1971) Fertilizer nitrogen:contribution to nitrate in surface water in a com belt watershed. Science 174: 1331-1334.

Lindegaard KN, Barker JHA (1996) Breeding willows for biomass. Asp Appl Biol 49: 155162 
Lopes MS, Araus JL (2006) Nitrogen source and water regime effects on durum wheat photosynthesis and stable carbon and nitrogen isotope composition. Physiologia Plantarum 126: 435-445

Manzano-Piedras E, Marcer A, Alonso-Blanco C, Picó FX (2014) Deciphering the adjustment between environment and life history in annuals: Lessons from a geographically-explicit approach in Arabidopsis thaliana. PLoS ONE 9: e87836

Mátyás C (1996) Climatic adaptation of trees: rediscovering provenance tests. Euphytica 92: 4554

McKown AD, Guy RD, Azam MS, Drewes EC, Quamme LK (2013) Seasonality and phenology alter functional leaf traits. Oecologia 172: 653-665

McKown AD, Guy RD, Klápště J, Geraldes A, Friedmann M, Cronk QCB, El-Kassaby YA, Mansfield SD, Douglas CJ (2014a) Geographical and environmental gradients shape phenotypic trait variation and genetic structure in Populus trichocarpa. New Phytol 201: $1263-1276$

McKown AD, Guy RD, Quamme L, Klápště J, La Mantia J, Constabel CP, El-Kassaby YA, Hamelin RC, Zifkin M, Azam MS (2014b) Association genetics, geography and ecophysiology link stomatal patterning in Populus trichocarpa with carbon gain and disease resistance trade-offs. Mol Ecol 23: 5771-5790

McMahon SM, Parker GG, Miller DR (2010) Evidence for a recent increase in forest growth. Proc Natl Acad Sci USA 107: 3611-3615

Milla-Moreno EA, McKown AD, Guy RD, Soolanayakanahally RY (2016) Leaf mass per area predicts palisade structural properties linked to mesophyll conductance in balsam poplar (Populus balsamifera L.). Botany 94: 225-239

Mooney HA, Billings WD (1961) Comparative physiological ecology of arctic and alpine populations of Oxyria digyna. Ecol Monogr 31: 1-29

Muir CD, Hangarter RP, Moyle LC, Davis PA (2014) Morphological and anatomical determinants of mesophyll conductance in wild relatives of tomato (Solanum sect. Lycopersicon, sect. Lycopersicoides; Solanaceae). Plant Cell Environ 37: 1415-1426

Oleksyn J, Modrzýnski J, Tjoelker MG, Z·ytkowiak R, Reich PB, Karolewski P (1998) Growth and physiology of Picea abies populations from elevational transects: common garden evidence for altitudinal ecotypes and cold adaptation. Func Ecol 12: 573-590

Pauley SS, Perry TO (1954) Ecotypic variation of the photoperiodic responses in Populus. Journal of the Arnold Arboretum, Harvard University 35: 167-188

Peñuelas J, Rutishauser T, Filella I (2009) Phenology feedbacks on climate change. Science 324: $887-888$

Piao S, Ciais P, Friedlingstein P, Peylin P, Reichstein M, Luyssaert S, Margolis H, Fang J, Barr A, Chen A, Grelle A, Hollinger DY, Laurila T, Lindroth A, Richardson AD, Vesala T (2008) Net carbon dioxide losses of northern ecosystems in response to autumn warming. Nature 451: 49-52

Pointeau VM, Guy RD (2014) Comparative resource-use efficiencies and growth of Populus trichocarpa and Populus balsamifera under glasshouse conditions. Botany 92: 443-451

Poorter H, Niinemets Ü, Poorter L, Wright IJ, Villar R (2009) Causes and consequences of variation in leaf mass per area (LMA): a meta-analysis. New Phytol 182: 565-588

Pucholt P, Sjödin P, Weih M, Rönnberg-Wästljung AC, Berlin S (2015) Genome-wide transcriptional and physiological responses to drought stress in leaves and roots of two willow genotypes. BMC Plant Biol 15: 1-16 
Robakowski P, Li Y, Reich PB (2012) Local ecotypic and species range-related adaptation influence photosynthetic temperature optima in deciduous broadleaved trees. Plant Ecol 213: $113-125$

Ryan NM (2015) Growth and cophysiology of wide intraspecific balsam poplar (P. balsamifera L.) hybrids. MSc thesis

Saska MM, Kuzovkina YA (2010) Phenological stages of willow (Salix). Ann Appl Biol 156: 431-437

Savage JA, Cavender-Bares JM (2011) Contrasting drought survival strategies of sympatric willows (genus: Salix): consequences for coexistence and habitat specialization. Tree Physiol 31: 604-614

Sharkey TD, Bernacchi CJ, Farquhar GD, Singsaas EL (2007) Fitting photosynthetic carbon dioxide response curves for C3 leaves. Plant Cell Environ 30: 1035-1040

Smart LB, Cameron KD (2008) Genetic improvement of willow (Salix spp.) as a dedicated bioenergy crop. In W Vermerris, ed, Genetic improvement of bioenergy crops. Springer New York, New York, NY, pp 377-396

Soolanayakanahally RY, Guy RD, Silim SN, Drewes EC, Schroeder WR (2009) Enhanced assimilation rate and water use efficiency with latitude through increased photosynthetic capacity and internal conductance in balsam poplar (Populus balsamifera L.). Plant Cell Environ 32: 1821-1832

Soolanayakanahally RY, Guy RD, Silim SN, Song M (2013) Timing of photoperiodic competency causes phenological mismatch in balsam poplar (Populus balsamifera L.). Plant Cell Environ 36: 116-127

Soolanayakanahally RY, Guy RD, Street N, Robinson K, Silim SN, Benedicte A, Jansson $\mathbf{S}$ (2015) Timing of photoperiodic competency causes phenological mismatch in balsam poplar (Populus balsamifera L.). Plant Cell Environ 36: 116-127

Stearns SC (1989) Trade-offs in life-history evolution. Func Ecol 3: 259-268

Théroux Rancourt G, Éthier G, Pepin S (2015) Greater efficiency of water use in poplar clones having a delayed response of mesophyll conductance to drought. Tree Physiol 35: $172-184$

Trybush SO, Jahodová Š, Čížková L, Karp A, Hanley SJ (2012) High Levels of genetic diversity in Salix viminalis of the Czech Republic as revealed by microsatellite markers. Bioenerg Res 5: 969-977

Tsarouhas V, Gullberg U, Lagercrantz ULF (2003) Mapping of quantitative trait loci controlling timing of bud flush in Salix. Hereditas 138: 172-178

Turner NC, Schulze E-D, Nicolle D, Kuhlmann I (2010) Growth in two common gardens reveals species by environment interaction in carbon isotope discrimination of Eucalyptus. Tree Physiol 30: 741-747

Wang R, Yu G, He N, Wang Q, Zhao N, Xu Z, Ge J (2015) Latitudinal variation of leaf stomatal traits from species to community level in forests: linkage with ecosystem productivity. Sci Rep 5: 14454

Weih M (2003) Trade-offs in plants and the prospects for breeding using modern biotechnology. New Phytol 158: 7-9

Weih M, Rönnberg-Wästjung A-C (2007) Shoot biomass growth is related to the vertical leaf nitrogen gradient in Salix canopies. Tree Physiol 27: 1551-1559 
917 Weih M (2009) Genetic and environmental variation in spring and autumn phenology of biomass willows (Salix spp.): effects on shoot growth and nitrogen economy. Tree Physiol 29: 1479-1490

Weih M, Bonosi L, Ghelardini L, Rönnberg-Wästljung AC (2011) Optimizing nitrogen economy under drought: increased leaf nitrogen is an acclimation to water stress in willow (Salix spp.). Ann Bot 108: 1347-1353

Withrow RB (1959) A kinetic analysis of photoperiodism. In RB Withrow, ed, Photoperiodism and related phenomena in plants and animals. American Association for Advancement of Science, Washington, DC, USA, pp 439-471

929

930

931

932

933

934

935

936

937

938

939

940

941

942

943

944

945

946

947

948

949

950

951

952

953

954

955

956

Worrall J (1993) Temperature effects on bud-burst and leaf-fall in subalpine larch. J Sustainable For 1: 1-18 
957 Table 1. Geo-climatic information of 34 native Salix eriocephala populations used in study. The 958 three letters within the brackets correspond to population code.

\begin{tabular}{|c|c|c|c|c|c|c|c|}
\hline Population & LAT & LON & ELV & FFD & MAP & MST & DD $>5$ \\
\hline La Ronge (LAR) & 55.00 & 105.21 & 390 & 151 & 484 & 11.2 & 1323 \\
\hline Grand Rapids (GRR) & 53.51 & 99.14 & 280 & 167 & 474 & 12 & 1508 \\
\hline Christopher Lake (CLK) & 53.30 & 105.45 & 531 & 154 & 424 & 12.1 & 1467 \\
\hline Camrose (CAM) & 52.55 & 112.51 & 689 & 165 & 438 & 13.6 & 1431 \\
\hline Easterville (EAS) & 52.55 & 99.10 & 282 & 158 & 443 & 11.5 & 1407 \\
\hline Wakaw (WAK) & 52.41 & 105.43 & 528 & 161 & 388 & 12.3 & 1517 \\
\hline Stettler (STL) & 52.17 & 113.15 & 800 & 159 & 478 & 13.6 & 1446 \\
\hline St. Martin Junction (SMJ) & 51.43 & 98.50 & 251 & 159 & 500 & 12.6 & 1588 \\
\hline Watrous (WAT) & 51.35 & 105.27 & 550 & 163 & 435 & 13 & 1628 \\
\hline Drumheller (DRU) & 51.28 & 112.43 & 683 & 160 & 338 & 13.9 & 1533 \\
\hline Ashern (ASH) & 51.07 & 98.22 & 264 & 159 & 500 & 12.6 & 1588 \\
\hline Bow River (BOW) & 50.47 & 112.38 & 791 & 169 & 515 & 13.6 & 1490 \\
\hline Indian Head (IHD) & 50.30 & 103.40 & 609 & 164 & 447 & 13.3 & 1671 \\
\hline Moose Jaw (MJW) & 50.22 & 105.49 & 669 & 176 & 365 & 14.1 & 1845 \\
\hline Portage La Prairie (POR) & 49.59 & 98.16 & 256 & 167 & 515 & 13.7 & 1784 \\
\hline Kipling (KIP) & 49.55 & 102.37 & 751 & 175 & 396 & 15.5 & 1848 \\
\hline Kenora (KEN) & 49.48 & 94.30 & 344 & 182 & 662 & 13.6 & 1759 \\
\hline Taber (TAB) & 49.48 & 112.10 & 754 & 170 & 316 & 14.9 & 1717 \\
\hline Fauquier (FAQ) & 49.18 & 82.02 & 224 & 151 & 832 & 11.2 & 1370 \\
\hline Deer Lake (DER) & 49.10 & 57.37 & 12 & 180 & 1127 & 10.9 & 1298 \\
\hline Morden (MDN) & 49.00 & 98.08 & 431 & 183 & 533 & 14.6 & 1955 \\
\hline Fort Frances (FTF) & 48.38 & 93.19 & 345 & 180 & 710 & 14 & 1821 \\
\hline Stephenville (STE) & 48.33 & 58.40 & 8 & 204 & 1352 & 11 & 1324 \\
\hline Thunder Bay (TBY) & 48.31 & 88.43 & 231 & 162 & 712 & 11.9 & 1434 \\
\hline Codroy Valley (COD) & 47.51 & 59.18 & 4 & 200 & 1709 & 9.4 & 1023 \\
\hline NB North (NBN) & 47.11 & 67.56 & 153 & 181 & 1134 & 12.6 & 1577 \\
\hline Quebec (QUE) & 46.98 & 70.71 & 15 & 184 & 1141 & 15.4 & 1707 \\
\hline Batchawana Bay (BAT) & 46.54 & 84.35 & 169 & 195 & 1011 & 13.4 & 1718 \\
\hline Field, Sturgeon river (STU) & 46.31 & 80.01 & 231 & 183 & 899 & 13.3 & 1705 \\
\hline Prince Edward Island (PEI) & 46.26 & 62.01 & 21 & 204 & 1078 & 13.1 & 1722 \\
\hline NB Central (NBC) & 46.13 & 67.42 & 116 & 178 & 1114 & 13.7 & 1768 \\
\hline NS Eastern (NSE) & 45.52 & 61.15 & 24 & 197 & 1505 & 12 & 1541 \\
\hline NB South (NBS) & 45.32 & 66.03 & 8 & 210 & 1154 & 14.2 & 1891 \\
\hline NS West (NSW) & 45.21 & 63.16 & 21 & 193 & 1202 & 13 & 1684 \\
\hline
\end{tabular}

959 LAT, latitude $\left({ }^{\circ} \mathrm{N}\right)$; LON, longitude $\left({ }^{\circ} \mathrm{W}\right)$; ELV, elevation (m); FFD, frost-free days (days); 960 MAP, mean annual precipitation $(\mathrm{mm})$; MST, mean summer temperature $\left({ }^{\circ} \mathrm{C}\right)$; DD $>5$, degree 961 days above $5^{\circ} \mathrm{C}\left({ }^{\circ} \mathrm{C}\right)$. 
96izable 2. Mean values for ecophysiology, phenology and biomass traits measured in 338 genotypes of Salix eriocephala.

964

\begin{tabular}{|c|c|c|}
\hline Trait & Mean value $( \pm$ SD) & Range \\
\hline \multicolumn{3}{|l|}{ Ecophysiology } \\
\hline$A$ & $17.87 \pm 2.74$ & $9.13-23.7$ \\
\hline$g_{\mathrm{s}}$ & $0.48 \pm 0.15$ & $0.07-0.9$ \\
\hline$E$ & $4.59 \pm 1.2$ & $1.13-7.59$ \\
\hline$W U E_{\mathrm{i}}$ & $40.12 \pm 13$ & $19.50-128.71$ \\
\hline PNUE & $15.4 \pm 3.61$ & $7.59-33.2$ \\
\hline$C \mathrm{i} / \mathrm{Ca}$ & $0.79 \pm 0.05$ & $0.44-0.89$ \\
\hline LMA & $4.27 \pm 0.64$ & $2.71-6.4$ \\
\hline SD & $91 \pm 26$ & $31-174$ \\
\hline $\mathrm{CCI}$ & $12.57 \pm 2.77$ & $6.53-22.27$ \\
\hline Leaf $\mathrm{N}$ & $120.16 \pm 26.09$ & $62.93-205.13$ \\
\hline Leaf $C: N$ & $16.19 \pm 2.69$ & $10.26-28.98$ \\
\hline Wood N & $95.06 \pm 19.32$ & $56.77-152.82$ \\
\hline Wood C:N & $7.13 \pm 3.65$ & $0.65-19.39$ \\
\hline$\Delta^{13} \mathrm{C}_{\text {leaf }}$ & $20.65 \pm 1.1$ & $16.86-23.18$ \\
\hline$\Delta^{13} \mathrm{C}_{\text {wood }}$ & $19.84 \pm 0.76$ & $17.44-22.16$ \\
\hline$\delta^{15} \mathrm{~N}_{\text {leaf }}$ & $9.85 \pm 2.99$ & $5.67-21.21$ \\
\hline$\delta^{15} \mathrm{~N}_{\text {wood }}$ & $7.09 \pm 2.57$ & $3.42-14.79$ \\
\hline
\end{tabular}

\section{Phenology}

Bud flush

$$
\begin{array}{rr}
140 \pm 1 & 136-143 \\
143 \pm 2 & 140-146 \\
274 \pm 10 & 216-294 \\
144 \pm 16 & 98-166 \\
284 \pm 16 & 238-305 \\
1 \pm 1 & 0-3
\end{array}
$$$$
\text { Leaf drop }
$$

Rust

\section{Biomass}

$\begin{array}{lrr}\text { Height gain } & 215.4 \pm 43.99 & 78-316 \\ \text { Biomass } & 1.04 \pm 0.56 & 0.03-3.62\end{array}$


$965 A$, photosynthetic assimilation rate $\left(\mu \mathrm{mol} \mathrm{CO}_{2} \mathrm{~m}^{-2} \mathrm{~s}^{-1}\right) ; g_{\mathrm{s}}$, stomatal conductance $\left(\mathrm{mol} \mathrm{H}_{2} \mathrm{O} \mathrm{m}^{-2} \mathrm{~s}^{-}\right.$ $\left.96{ }^{1}\right) ; E$, transpiration rate $\left(\mathrm{mmol} \mathrm{H}_{2} \mathrm{O} \mathrm{m} \mathrm{m}^{-2}\right) ; W U E_{\mathrm{i}}$, intrinsic water-use efficiency $\left(\mu \mathrm{mol} \mathrm{CO}_{2}\right.$ $967 \mathrm{mmol}^{-1} \mathrm{H}_{2} \mathrm{O}$ ); PNUE, photosynthetic nitrogen-use efficiency $\left(\mu \mathrm{mol} \mathrm{CO} \mathrm{mol}^{-1} \mathrm{~N} \mathrm{~s}^{-1}\right) ; C_{\mathrm{i}} / C_{\mathrm{a}}$, ratio 968 of intercellular $\mathrm{CO}_{2}$ to external $\mathrm{CO}_{2}$ concentrations; LMA, leaf mass per unit area $\left(\mathrm{mg} \mathrm{cm}^{-2}\right) ; \mathrm{SD}$, 969 stomatal density $\left(\mathrm{mm}^{-2}\right)$; CCI, chlorophyll content index; leaf $\mathrm{N}$, nitrogen content per unit area $970\left(\mu \mathrm{mol} \mathrm{N} \mathrm{cm}{ }^{-2}\right) ; \mathrm{C}: \mathrm{N}$, carbon to nitrogen ratio; $\Delta^{13} \mathrm{C}$, net carbon discrimination $(\% o) ; \delta^{15} \mathrm{~N}$, stable 971 nitrogen isotope ratio (\%o); GCD, green cover duration (days); leaf drop (Julian day, DOY); 972 height gain $(\mathrm{cm})$; biomass $(\mathrm{kg})$.

973

974

975

976

977

978

979

980

981

982

983

984

985

986

987

988

989

990

991

992

993

994

995

996

997

998

999

1000

1001

1002

1003

1004

1005

1006 
Table 3. Pearson correlations coefficients ( $r$ ) between geography, climate and physiological variables for all 338 genotypes. Bold are significant after Bonferroni correction $(P<0.001)$.

\begin{tabular}{|c|c|c|c|c|c|c|c|}
\hline Trait variables & LAT & LON & ELV & FFD & MAP & MST & DD $>5$ \\
\hline$A$ & 0.57 & 0.7 & 0.66 & -0.51 & -0.65 & 0.23 & 0.04 \\
\hline$g_{\mathrm{s}}$ & 0.34 & 0.54 & 0.53 & -0.34 & -0.45 & 0.24 & 0.03 \\
\hline$E$ & 0.19 & 0.49 & 0.57 & -0.26 & -0.36 & 0.37 & 0.12 \\
\hline$W U E_{\mathrm{i}}$ & -0.18 & -0.36 & -0.34 & 0.24 & 0.27 & -0.18 & -0.03 \\
\hline PNUE & 0.04 & 0.16 & 0.21 & -0.06 & -0.11 & 0.17 & 0.01 \\
\hline$C_{\mathrm{i}} / C_{\mathrm{a}}$ & 0.14 & 0.31 & 0.28 & -0.2 & -0.22 & 0.16 & 0.03 \\
\hline LMA & 0.26 & 0.24 & 0.13 & -0.2 & -0.27 & -0.04 & 0.12 \\
\hline SD & -0.44 & -0.44 & -0.32 & 0.35 & 0.42 & 0 & 0.02 \\
\hline CCI & 0.35 & 0.29 & 0.32 & -0.22 & -0.28 & -0.07 & -0.15 \\
\hline Leaf N & 0.39 & 0.34 & 0.25 & -0.32 & -0.37 & -0.01 & 0.03 \\
\hline Leaf C:N & -0.22 & -0.15 & -0.11 & 0.19 & 0.17 & 0.06 & 0.09 \\
\hline Wood N & 0.13 & 0.09 & -0.01 & -0.12 & -0.08 & 0.06 & 0.02 \\
\hline Wood C:N & 0.03 & 0.16 & 0.27 & -0.04 & -0.08 & 0.24 & -0.08 \\
\hline$\Delta^{13} \mathrm{C}_{\text {leaf }}$ & 0.05 & 0.1 & 0.07 & -0.06 & -0.08 & 0.03 & 0.03 \\
\hline$\Delta^{13} \mathrm{C}_{\text {wood }}$ & 0.06 & 0.15 & 0.03 & -0.08 & -0.17 & 0.11 & 0.16 \\
\hline$\delta^{15} \mathrm{~N}_{\text {leaf }}$ & 0.39 & 0.43 & 0.35 & -0.35 & -0.39 & 0.09 & 0.08 \\
\hline$\delta^{15} \mathrm{~N}_{\text {wood }}$ & 0.36 & 0.35 & 0.24 & -0.31 & -0.33 & -0.01 & 0.08 \\
\hline Bud flush & -0.02 & 0.01 & 0.08 & -0.03 & -0.04 & 0.1 & 0.02 \\
\hline Leaf emergence & 0.04 & 0.12 & 0.18 & -0.09 & -0.13 & 0.18 & 0.08 \\
\hline Leaf senescence & -0.57 & -0.68 & -0.61 & 0.52 & 0.64 & -0.11 & -0.05 \\
\hline GCD & -0.74 & -0.82 & -0.77 & 0.68 & 0.79 & -0.18 & -0.01 \\
\hline Leaf drop & -0.74 & -0.83 & -0.77 & 0.69 & 0.79 & -0.18 & -0.01 \\
\hline Rust & 0.62 & 0.79 & 0.83 & -0.56 & -0.77 & 0.31 & 0.1 \\
\hline Height gain & 0.25 & 0.24 & 0.04 & -0.23 & -0.31 & -0.1 & 0.14 \\
\hline Biomass & 0.18 & 0.31 & 0.34 & -0.21 & -0.28 & 0.17 & 0.04 \\
\hline
\end{tabular}

1011 LAT, latitude $\left({ }^{\circ} \mathrm{N}\right)$; LON, longitude $\left({ }^{\circ} \mathrm{W}\right)$; ELV, elevation (m); FFD, frost-free days (days); 1012 MAP, mean annual precipitation (mm); MST, mean summer temperature $\left({ }^{\circ} \mathrm{C}\right)$; DD $>5$, degree 1013 days above $5^{\circ} \mathrm{C}\left({ }^{\circ} \mathrm{C}\right) ; A$, photosynthetic assimilation rate $\left(\mu \mathrm{mol} \mathrm{CO}_{2} \mathrm{~m}^{-2} \mathrm{~s}^{-1}\right) ; g_{\mathrm{s}}$, stomatal 1014 conductance $\left(\mathrm{mol} \mathrm{H}_{2} \mathrm{O} \mathrm{m}^{-2} \mathrm{~s}^{-1}\right) ; E$, transpiration rate $\left(\mathrm{mmol} \mathrm{H}_{2} \mathrm{O} \mathrm{m}^{-2} \mathrm{~s}^{-1}\right)$; $W U E_{\mathrm{i}}$, intrinsic water1015 use efficiency ( $\mu \mathrm{mol} \mathrm{CO} \mathrm{mmol}^{-1} \mathrm{H}_{2} \mathrm{O}$ ); PNUE, photosynthetic nitrogen-use efficiency $(\mu \mathrm{mol}$ 
$\left.1016 \mathrm{CO}_{2} \mathrm{~mol}^{-1} \mathrm{~N} \mathrm{~s}^{-1}\right) ; C_{\mathrm{i}} / C_{\mathrm{a}}$, ratio of intercellular $\mathrm{CO}_{2}$ to external $\mathrm{CO}_{2}$ concentrations; $\mathrm{LMA}$, leaf 1017 mass per unit area $\left(\mathrm{mg} \mathrm{cm}^{-2}\right)$; SD, stomatal density $\left(\mathrm{mm}^{-2}\right)$; CCI, chlorophyll content index; leaf $1018 \mathrm{~N}$, nitrogen content per unit area $\left(\mu \mathrm{mol} \mathrm{N} \mathrm{cm}{ }^{-2}\right) ; \mathrm{C}: \mathrm{N}$, carbon to nitrogen ratio; $\Delta^{13} \mathrm{C}$, net carbon 1019 discrimination $(\% \circ) ; \delta^{15} \mathrm{~N}$, stable nitrogen isotope ratio (\%o); GCD, green cover duration (days); 1020 leaf drop (Julian day, DOY); height gain $(\mathrm{cm})$; biomass $(\mathrm{kg})$.

1021

1022

1023

1024

1025

1026

1027

1028

1029

1030

1031

1032

1033

1034

1035

1036

1037

1038

1039

1040

1041

1042

1043

1044

1045

1046

1047

1048

1049

1050

1051

1052

1053

1054

1055

1056

1057

1058

1059 

aCC-BY-ND 4.0 International license.

1060 Table 4. Broad-sense heritability $\left(H^{2}\right)$ estimates of phenology and biomass traits in 2015.

1061

\section{Traits}

\section{Heritability $\left(\boldsymbol{H}^{2}\right)$}

\begin{tabular}{ll}
\hline Bud flush & 0.72 \\
Leaf emergence & 0.77 \\
Leaf senescence & 0.62 \\
Leaf drop & 0.78 \\
Height & 0.95 \\
Biomass & 0.88 \\
\hline
\end{tabular}

1062

1063

1064

1065

1066

1067

1068

1069

1070

1071

1072

1073

1074

1075

1076

1077

1078 
Figure legends

1080

1081

1082

1083

1084

1085

1086

1087

1088

1089

1090

1091

1092

1093

1094

1095

1096

1097

1098

1099

1100

1101

1102

1103

1104

1105

1106

1107

1108

1109

1110

1111

1112

1113

1114

Figure 1A. Geographical distribution of 34 native populations (blue circle) of Salix eriocephala from their natural ranges across eastern and western Canada. The green color depicts species dominant continuous range while the yellow shaded area is species discontinues range. The common garden was established at Indian Head, Saskatchewan, Canada.

Figure 1B. Mean temperature (red line) and precipitation (blue line) that prevailed at Indian Head common garden during 2013 and 2014. The green band represents the spring bud flush period, whereas, the yellow band represents leaf senescence duration among Salix eriocephala populations.

Figure 2. Seasonal phenological timetable of Salix eriocephala. Plants become dormant in autumn (fall) and remain so until chilling requirements are during winter (white band); during spring, heat sum accumulation leads to bud flush and leaf emergence (red band); free growth and carbon gain occur after leaf emergence (green band); growth cessation and leaf senescence during late summer and early autumn (yellow band).

Figure 3. Heat map of Pearson's correlation coefficient for phenotypic traits among 338 populations of Salix eriocephala. The scale bar beneath the heat map denotes the direction/ magnitude of correlation between the traits, 1 indicated by dark blue being positive and -1 indicated by dark red being negative.

Figure 4. A. Carbon isotope discrimination as determined on leaves $\left(\Delta^{13} \mathrm{C}_{\text {leaf }}\right)(\triangle)$ and wood $\left(\Delta^{13} \mathrm{C}_{\text {wood }}\right)(\square)$ and $\mathbf{B}$. Nitrogen isotope composition of leaves $\left(\delta^{15} \mathrm{~N}_{\text {leaf }}\right)(\triangle)$ and wood $\left(\delta^{15} \mathrm{~N}_{\text {wood }}\right)$ $(\square)$ of Salix eriocephala populations plotted against their latitude of origin.

Figure 5. The relationship between stomatal dimensions and maximum leaf condutcances of selected eastern and western populations of Salix eriocephala. A. Mean stomatal pore length (SL, $\mu \mathrm{m}$, images above the boxes represent stomatal pore length from respective latitudes viewed under 100× magnification using phase contrast microscopy), B. mean stomatal density (SD), C. stomatal conductance to carbon dioxide and water vapor $\left(g_{s}, \mathrm{~mol} \mathrm{H}_{2} \mathrm{O} \mathrm{m}^{-2} \mathrm{~s}^{-1}\right)$ and D. maximum

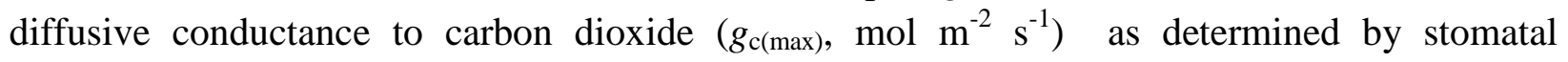
dimensions of eastern (NBS, NSW, PEI and QUE) and western (DRU, IHD, KEN and MDN) populations.

Figure 6. Gas exchange traits of selected eastern and western populations of Salix eriocephala. A. Internal conductance $\left(g_{\mathrm{m}}, \mathrm{mol} \mathrm{CO}_{2} \mathrm{~m}^{-2} \mathrm{~s}^{-1}\right)$, B. Maximum carboxylation rate allowed by rubisco $\left(V_{\mathrm{cmax}}, \mu \mathrm{mol} \mathrm{m} \mathrm{m}^{-2} \mathrm{~s}^{-1}\right)$, C. rate of photosynthetic electron transport based on NADPH requirement $\left(\mathrm{J}, \mu \mathrm{mol} \mathrm{m} \mathrm{s}^{-2} \mathrm{~s}^{-1}\right)$ and $\mathbf{D}$. Triose phosphate use (TPU, $\mu \mathrm{mol} \mathrm{m} \mathrm{m}^{-2} \mathrm{~s}^{-1}$ ) of eastern (NBN and NBS) and western (CLK, MJW and WAK) populations estimated using Sharkey's $A-C_{i}$ curve fitting model. $\mathrm{J}$ was significantly different $(P<0.05)$ between the eastern and western populations. 
1116 Figure 7. Melampsora rust incidence score of Salix eriocephala populations plotted against their

1117 latitude of origin. The images indicate the rust incidence scoring key, 0 for no rust and 1,2 and 3

1118 for minimum, moderate and maximum rust symptoms in the leaves, respectively.

1119 
Fig. 1A

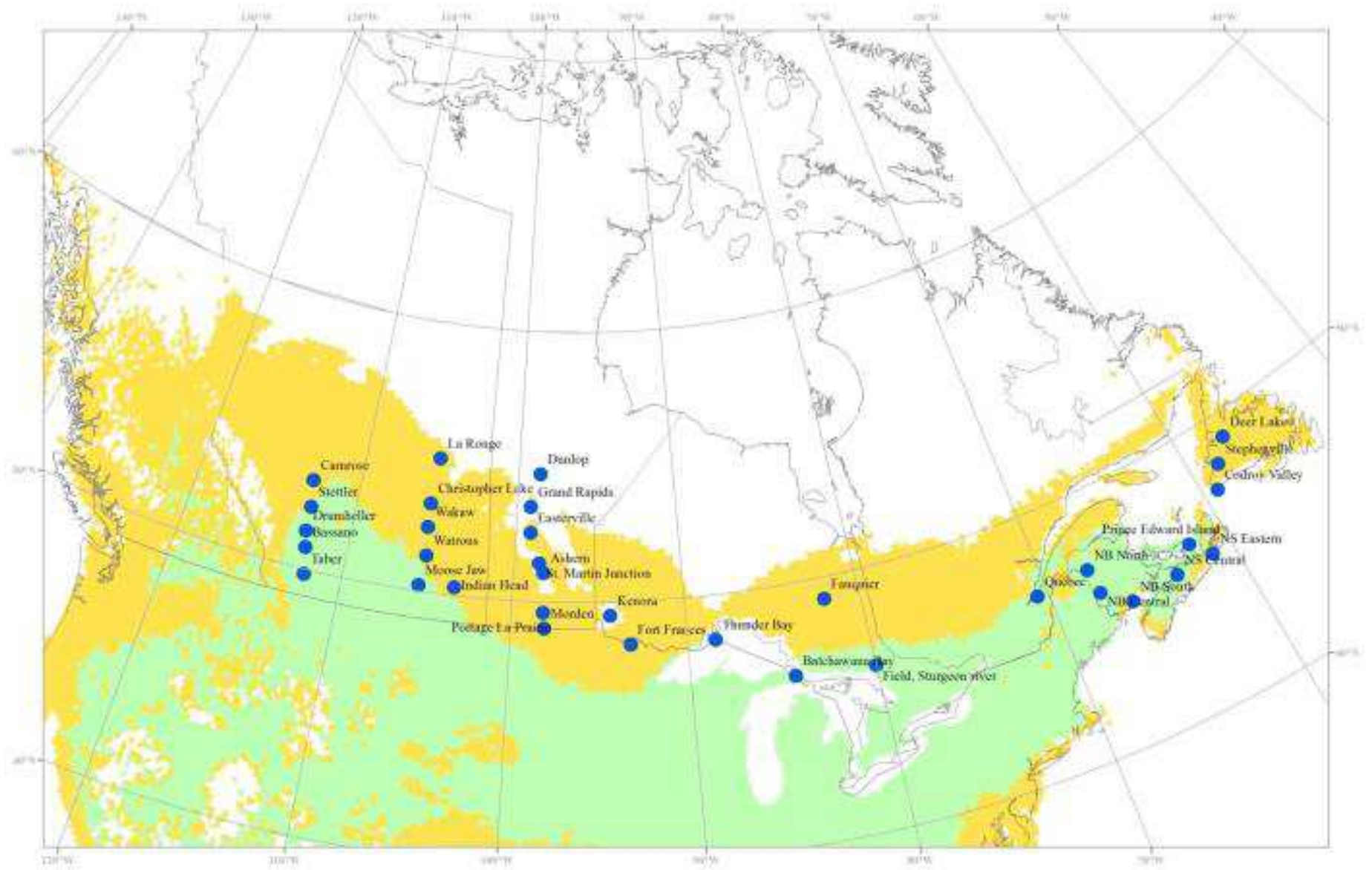


Fig. 1B

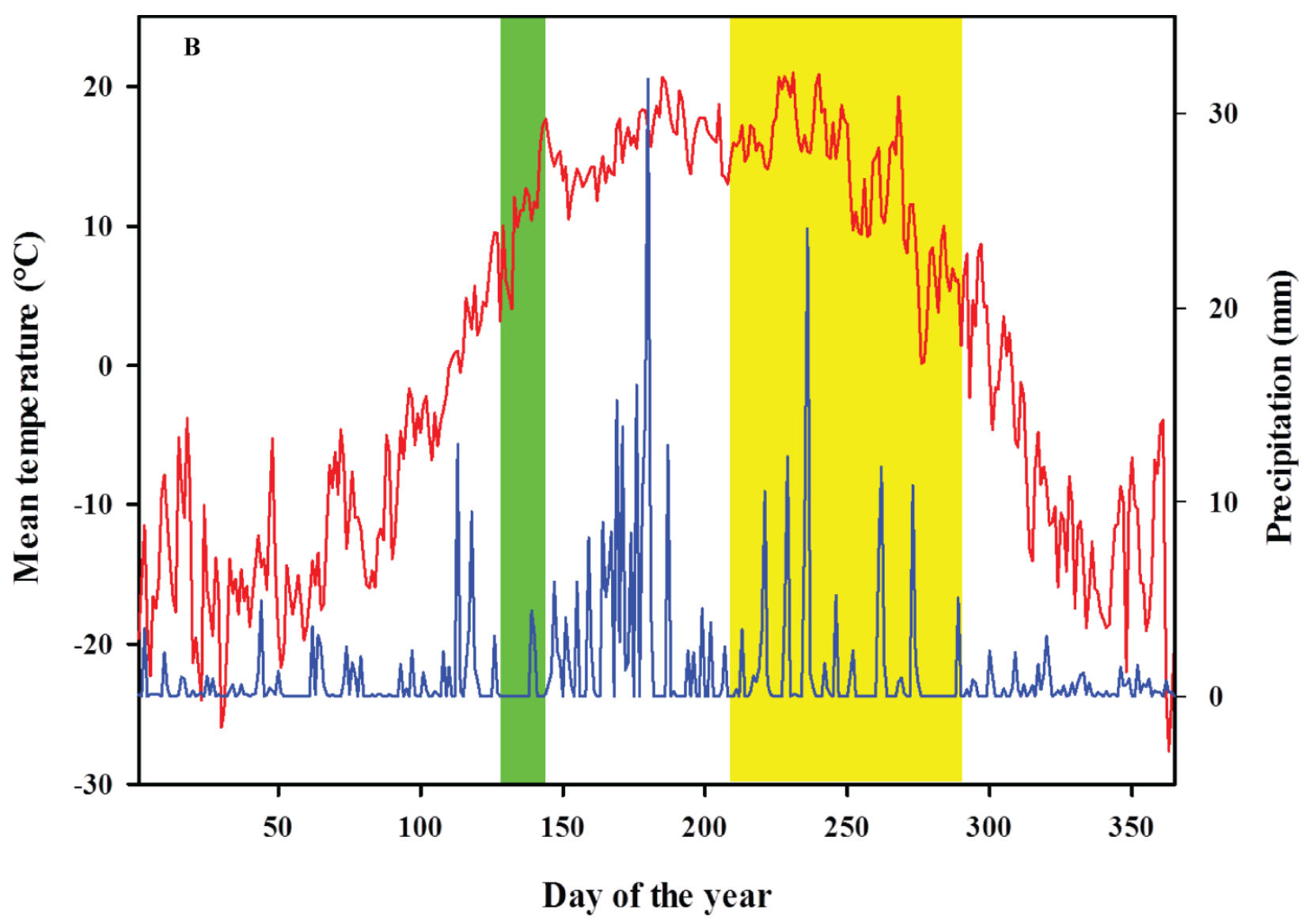


bioRxiv preprint doi: https://doi.org/10.1101/057745; this version posted June 8, 2016. The copyright holder for this preprint (which was not certified by peer review) is the author/funder, who has granted bioRxiv a license to display the preprint in perpetuity. It is made available under aCC-BY-ND 4.0 International license.

Fig. 2

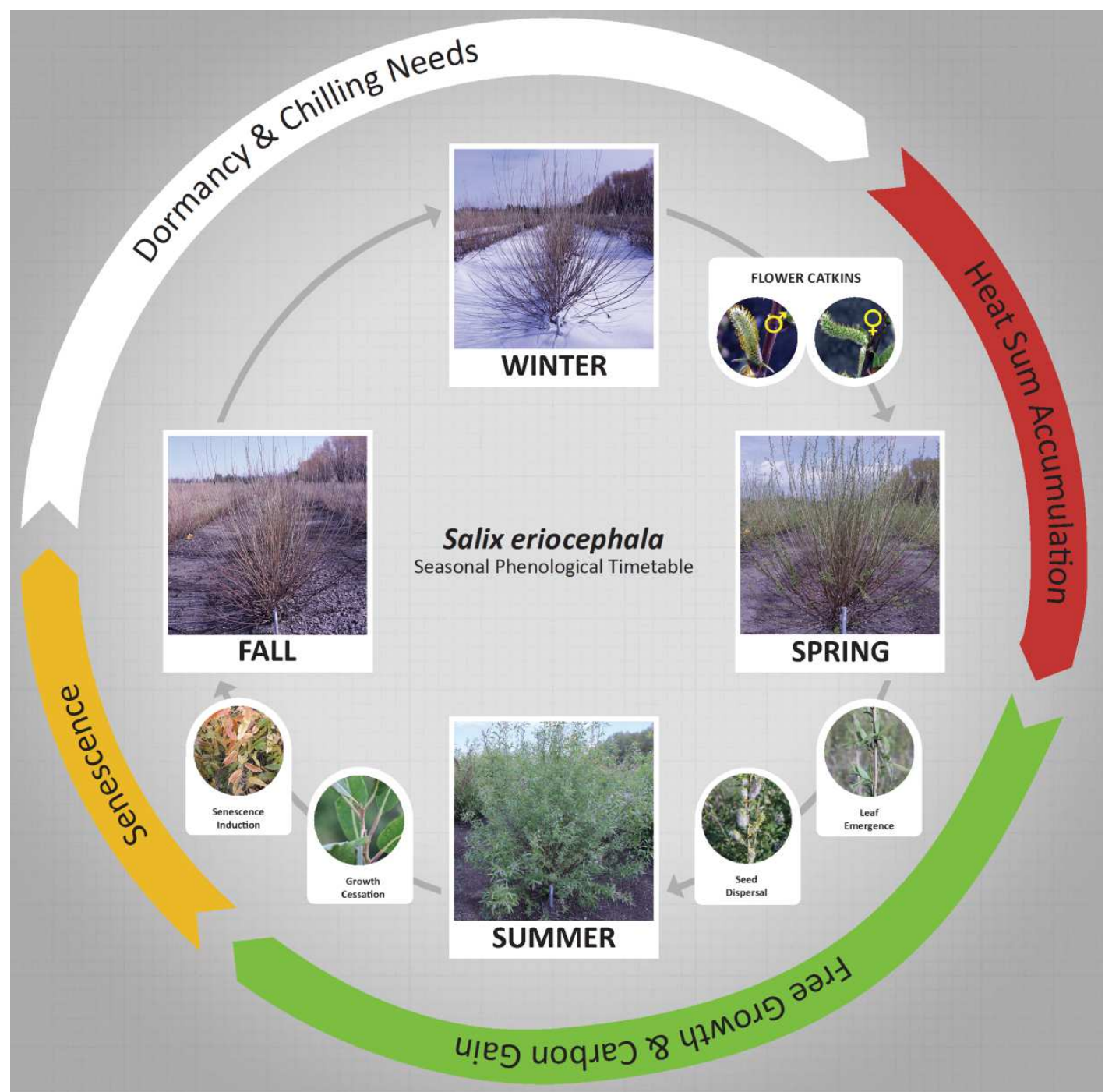


bioRxiv preprint doi: https://doi.org/10.1101/057745; this version posted June 8, 2016. The copyright holder for this preprint (which was not certified by peer review) is the author/funder, who has granted bioRxiv a license to display the preprint in perpetuity. It is made available under aCC-BY-ND 4.0 International license.

Fig. 3

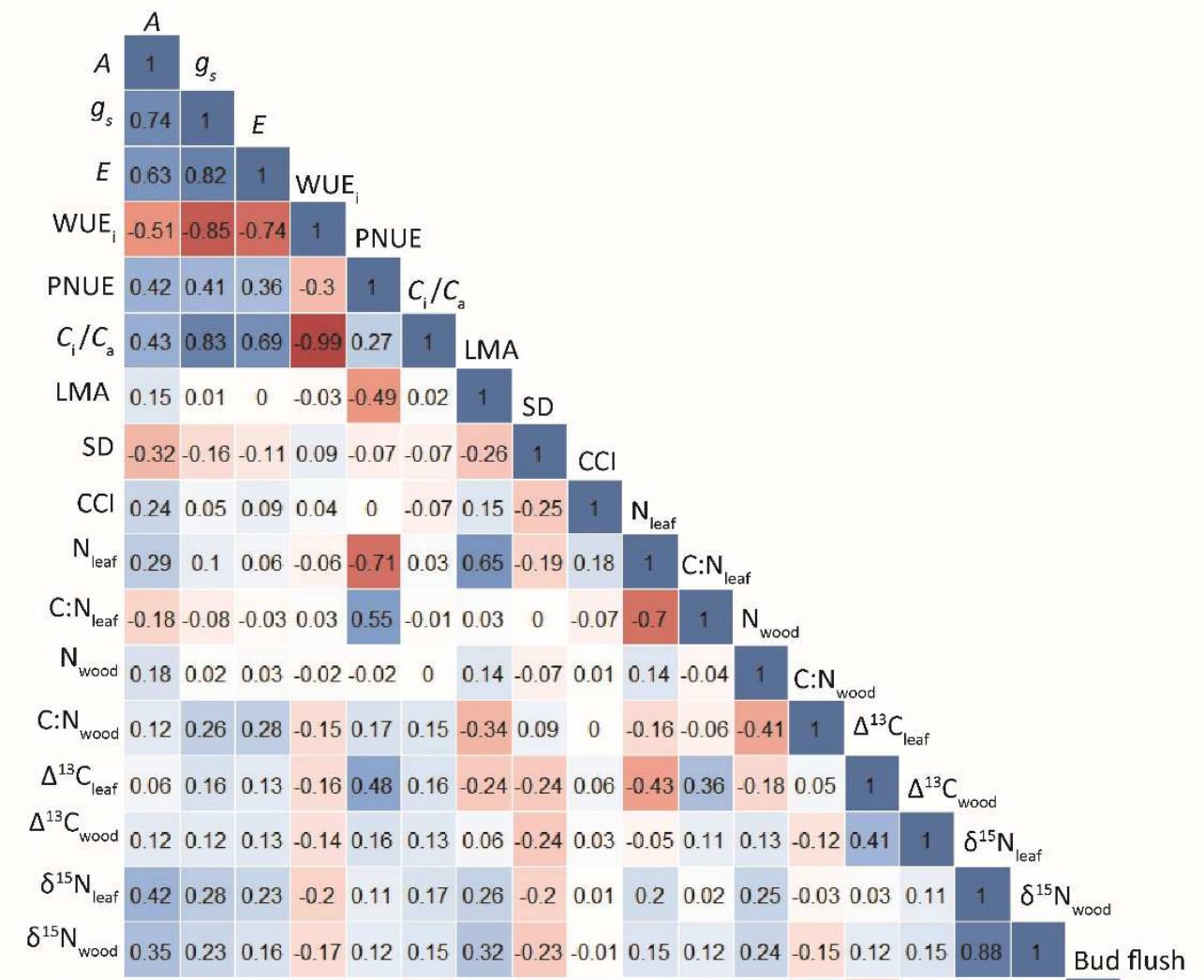

$\begin{array}{llllllllllllllllllll}\text { Bud flush } & 0.04 & 0 & 0.03 & 0.06 & 0 & -0.07 & 0.03 & 0.01 & 0.03 & 0.01 & 0.03 & 0.03 & 0.09 & -0.16 & -0.03 & 0.07 & -0.01 & 1 & \text { Leaf emergence }\end{array}$ $\begin{array}{lllllllllllllllllllllll}\text { Leaf emergence } & 0.04 & 0.01 & 0.15 & 0.05 & -0.04 & -0.06 & 0.04 & -0.07 & 0.25 & 0.06 & -0.01 & 0.04 & 0.14 & -0.06 & 0.06 & 0 & -0.08 & 0.48 & 1 & \text { Leaf senescence }\end{array}$ $\begin{array}{lllllllllllllllllllllllllllll}\text { Leaf senescence } & -0.51 & -0.34 & -0.3 & 0.2 & -0.13 & -0.16 & -0.27 & 0.42 & -0.26 & -0.27 & 0.07 & -0.11 & -0.02 & -0.11 & -0.16 & -0.34 & -0.32 & 0.02 & -0.03 & 1 & \text { GCD }\end{array}$

GCD $-0.62-0.45-0.390 .26-0.18-0.22-0.24 \quad 0.4-0.23-0.290 .1 \quad-0.06-0.16-0.12-0.1 \quad-0.4-0.36-0.09-0.120 .75 \quad 1$ Leaf drop

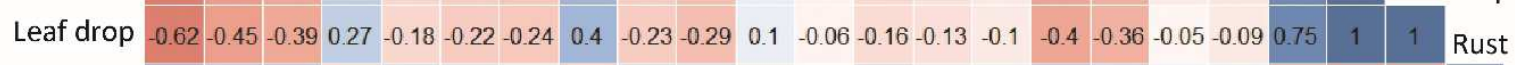

$\begin{array}{llllllllllllllllllllllllllll}\text { Rust } & 0.62 & 0.44 & 0.45 & -0.24 & 0.22 & 0.19 & 0.15 & -0.32 & 0.22 & 0.24 & -0.09 & 0 & 0.22 & 0.12 & 0.11 & 0.44 & 0.35 & 0.07 & 0.11 & -0.56 & -0.71 & -0.7 & 1 & \text { Height gain }\end{array}$

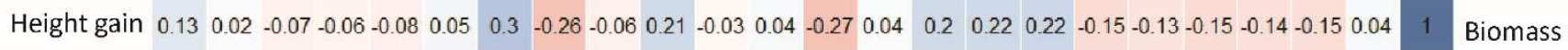

$\begin{array}{lllllllllllllllllllllllllll}\text { Biomass } & 0.22 & 0.18 & 0.16 & -0.14 & 0.11 & 0.12 & -0.07 & -0.11 & 0.01 & 0.07 & -0.08 & -0.2 & 0.2 & -0.02 & 0 & 0.06 & 0 & -0.07 & -0.1 & -0.21 & -0.21 & -0.22 & 0.31 & 0.08 & 1\end{array}$

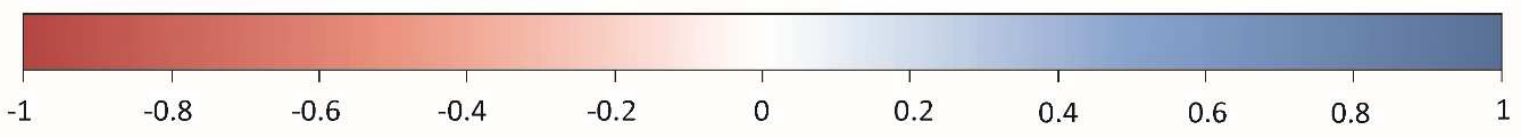


bioRxiv preprint doi: https://doi.org/10.1101/057745; this version posted June 8, 2016. The copyright holder for this preprint (which was not certified by peer review) is the author/funder, who has granted bioRxiv a license to display the preprint in perpetuity. It is made available under aCC-BY-ND 4.0 International license.

Fig. 4

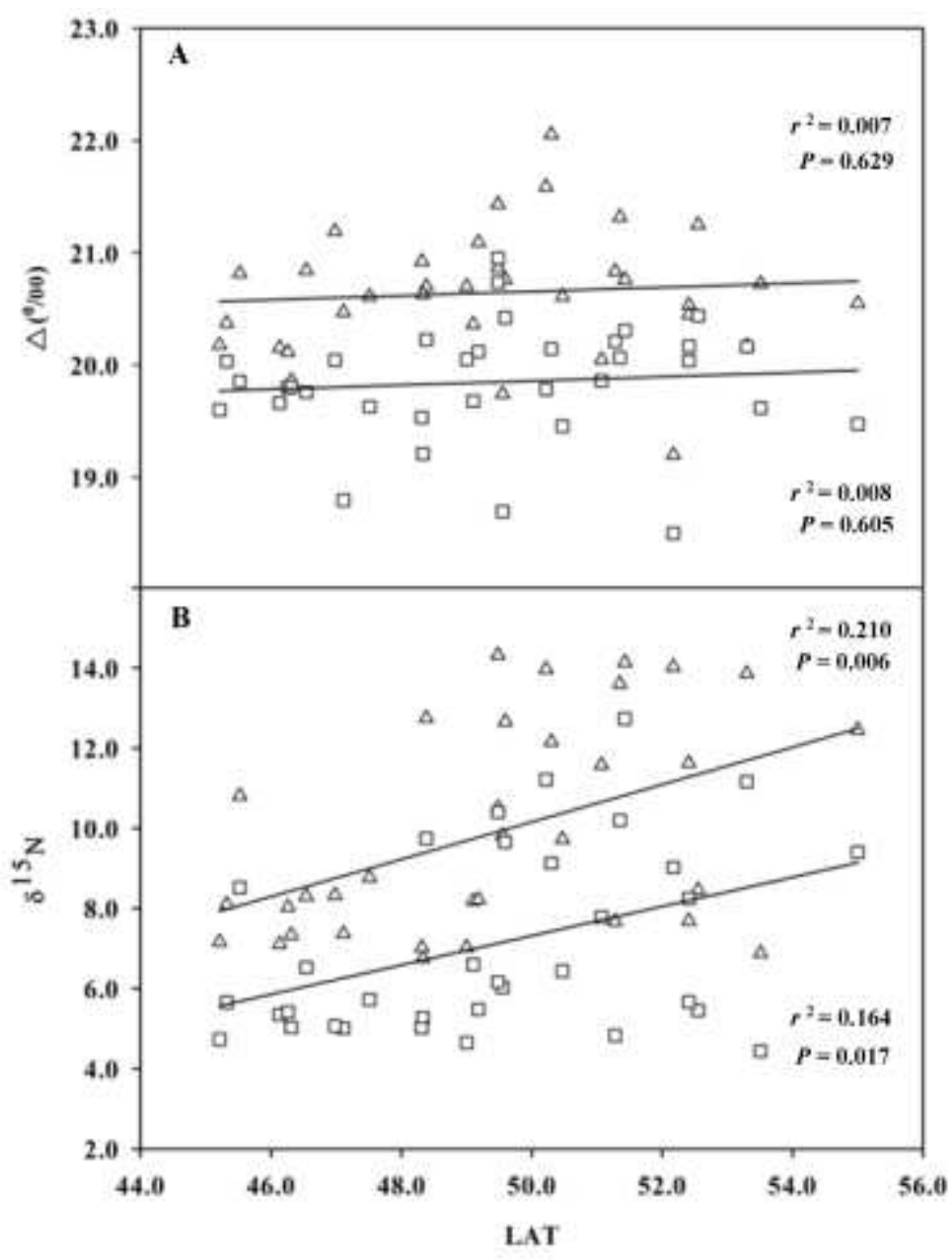


bioRxiv preprint doi: https://doi.org/10.1101/057745; this version posted June 8, 2016. The copyright holder for this preprint (which was not certified by peer review) is the author/funder, who has granted bioRxiv a license to display the preprint in perpetuity. It is made available under aCC-BY-ND 4.0 International license.

Fig. 5

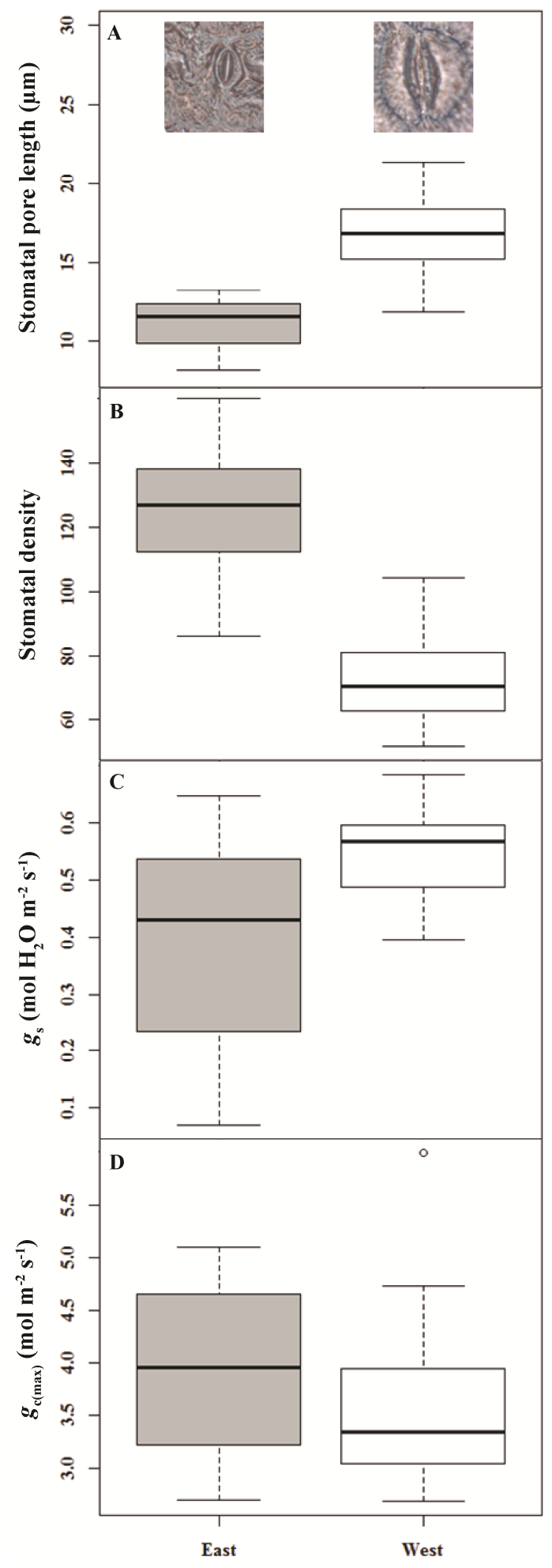


bioRxiv preprint doi: https://doi.org/10.1101/057745; this version posted June 8, 2016. The copyright holder for this preprint (which was not certified by peer review) is the author/funder, who has granted bioRxiv a license to display the preprint in perpetuity. It is made available under aCC-BY-ND 4.0 International license.

Fig. 6

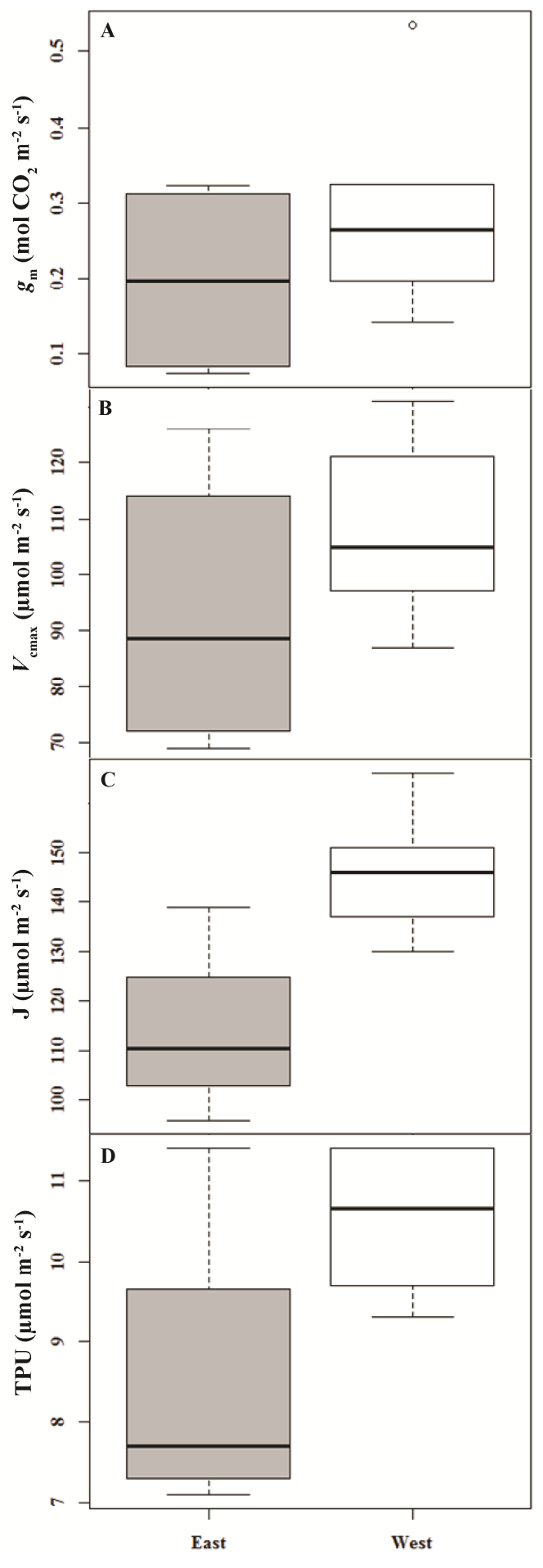


bioRxiv preprint doi: https://doi.org/10.1101/057745; this version posted June 8, 2016. The copyright holder for this preprint (which was not certified by peer review) is the author/funder, who has granted bioRxiv a license to display the preprint in perpetuity. It is made available under aCC-BY-ND 4.0 International license.

Fig. 7

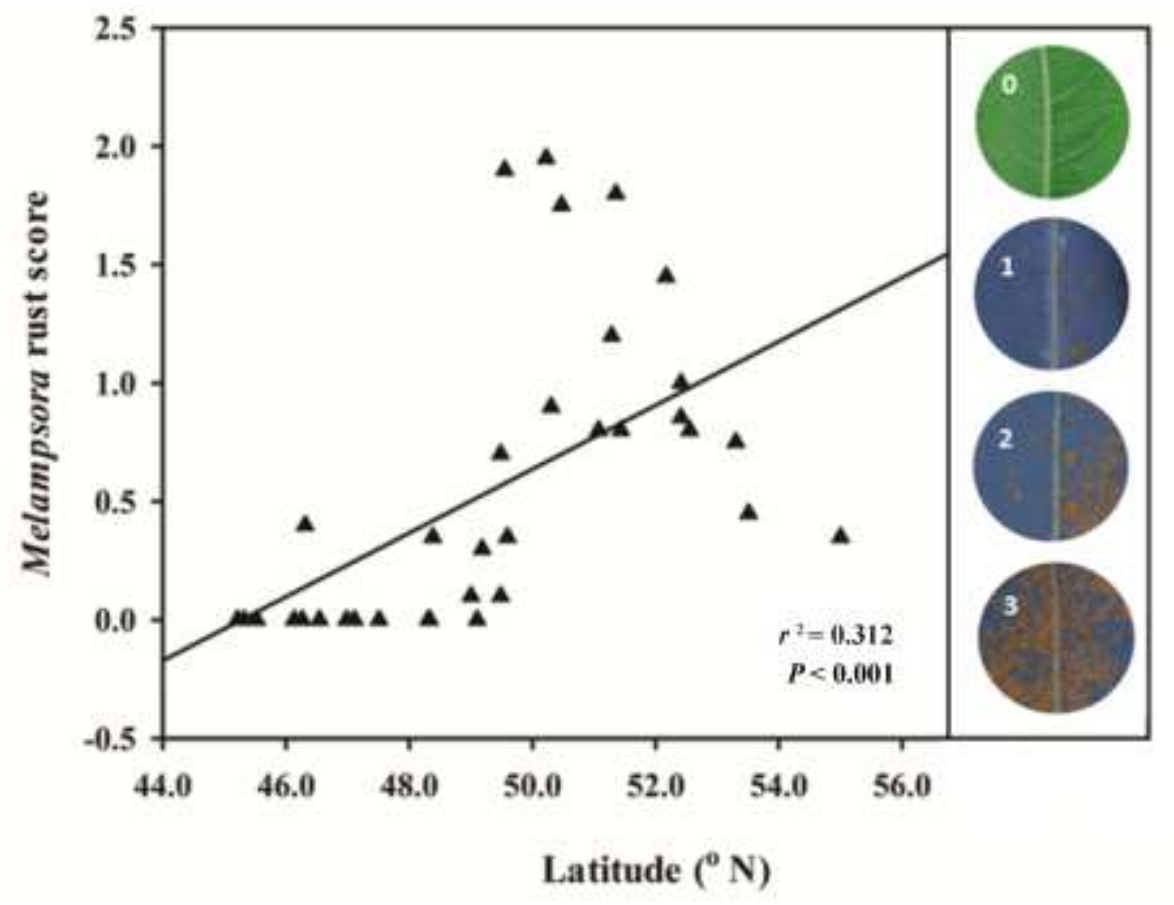




\section{Supplementary Table 1 (ST1)}

Soil analysis results from $15 \mathrm{~cm}$ depth at Indian Head common garden, Saskatchewan in 2012. Values shown are means \pm SD of nine individual samples analyzed from sandy clay loam texture soil.

\begin{tabular}{lr}
\hline Soil nutrient composition & Mean \pm SD \\
\hline $\mathrm{pH}$ & $7.9 \pm 0.28$ \\
Organic matter (\%) & $2.2 \pm 0.39$ \\
Salts (mmhos/cm) & $0.3 \pm 0.104$ \\
Nitrate nitrogen $(\mathrm{N}$ ppm) & $13.6 \pm 2.41$ \\
Ammonium nitrogen $(\mathrm{N}$ ppm) & $1.5 \pm 0.26$ \\
Olsen phosphorus (P ppm) & $19.7 \pm 6.92$ \\
Potassium (K ppm) & $242.9 \pm 56.55$ \\
Calcium $(\mathrm{Ca}$ ppm) & $3497.4 \pm 950.44$ \\
Magnesium (Mg ppm) & $534.3 \pm 87.02$ \\
Sodium (Na ppm) & $20.3 \pm 2.82$ \\
Chlorine (Cl ppm) & $3.1 \pm 0.84$ \\
Cation Exchange Capacity (CEC meq) & $22.7 \pm 4.68$ \\
Sand (\%) & $58.3 \pm 6.92$ \\
Silt (\%) & $20.8 \pm 4.05$ \\
Clay (\%) & $20.9 \pm 3.17$ \\
\hline
\end{tabular}


Supplementary Figure 1 (SF1): Pictorial description of site preparation, planting, management and trait measurements in the common garden at Indian Head research station, Canada.

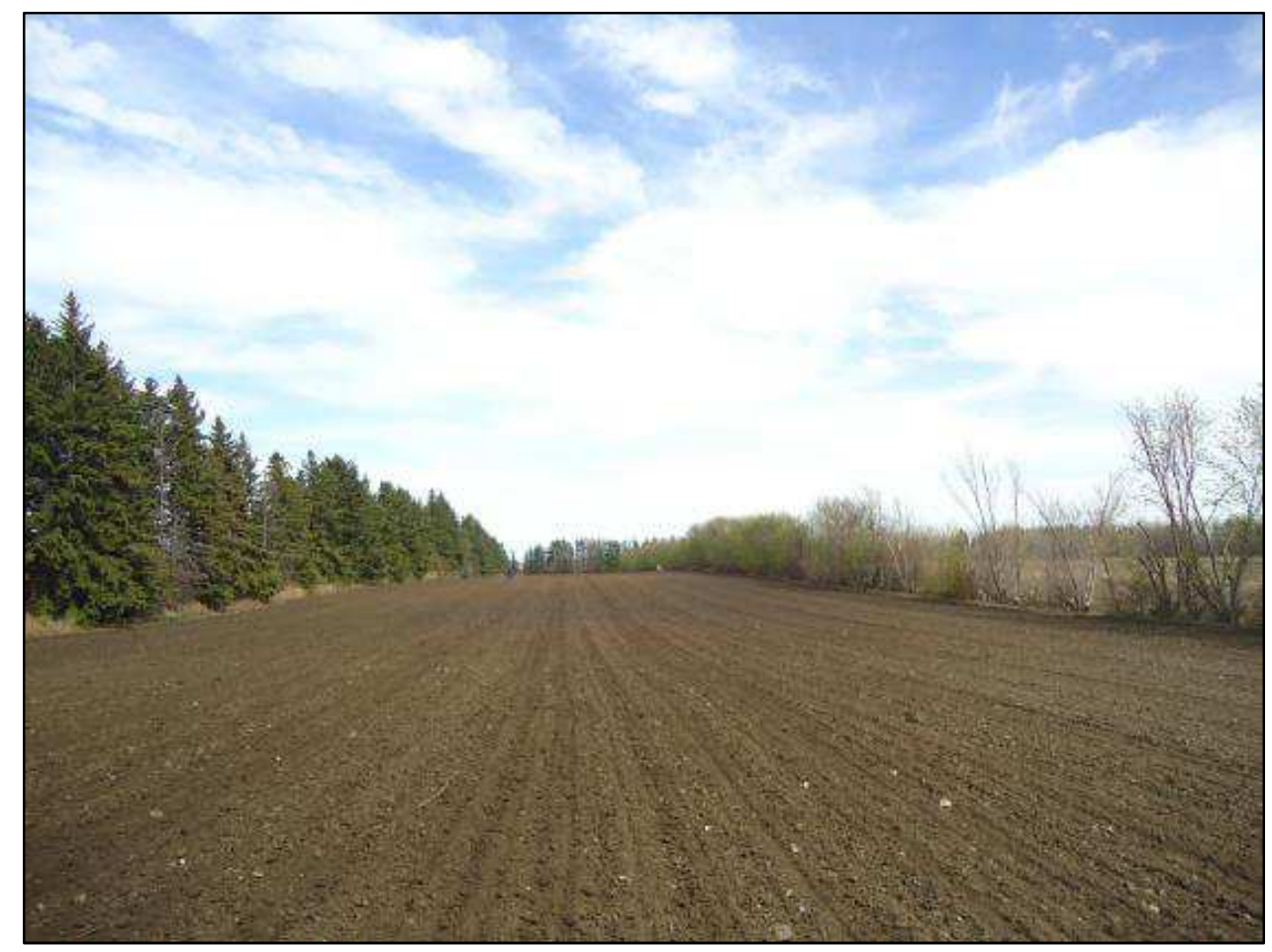

SF1 A. Common garden site preparation prior to willow planting.

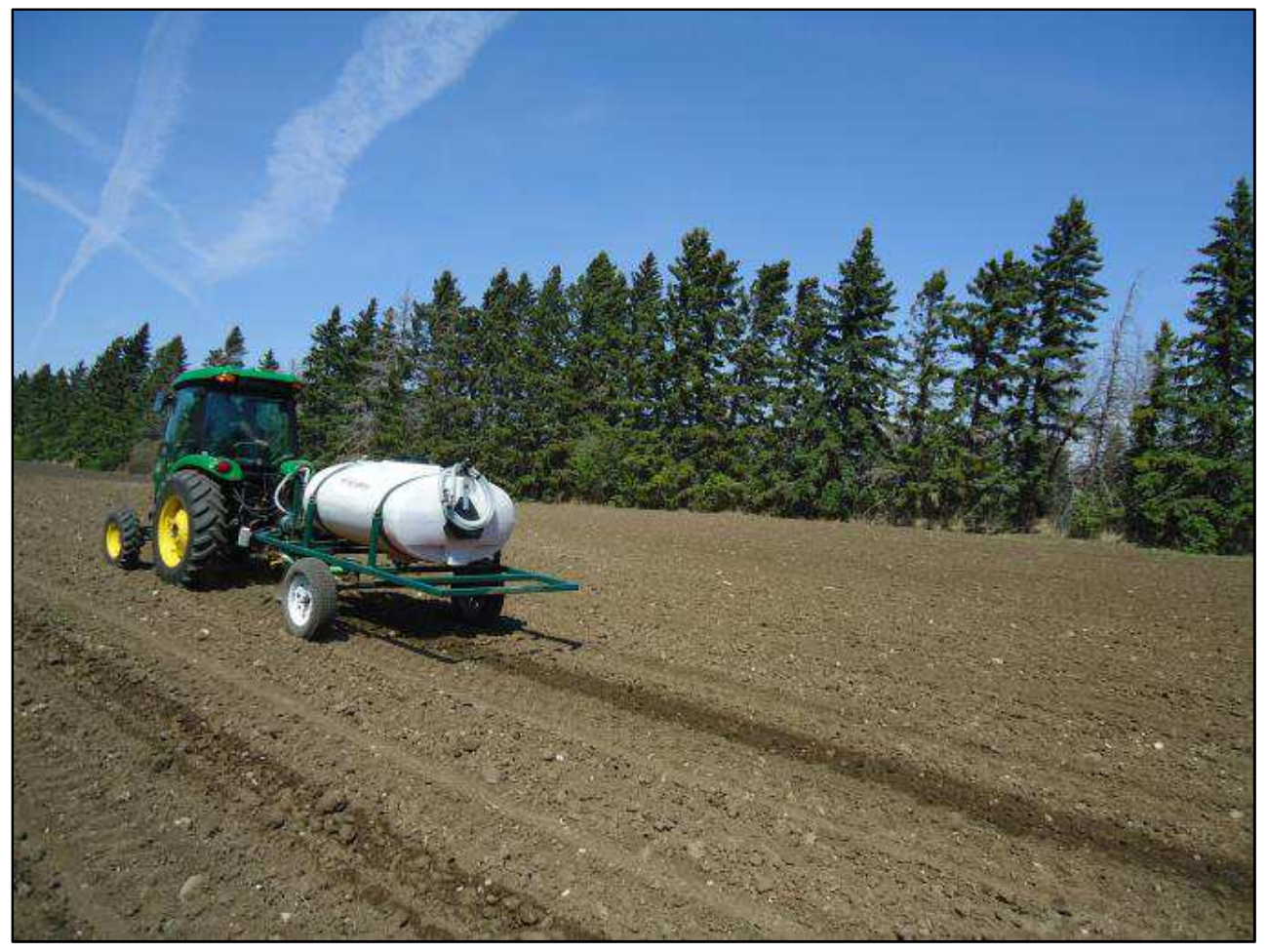


SF1 B. Nutrient amendments to sandy clay loam soils along planting strips.

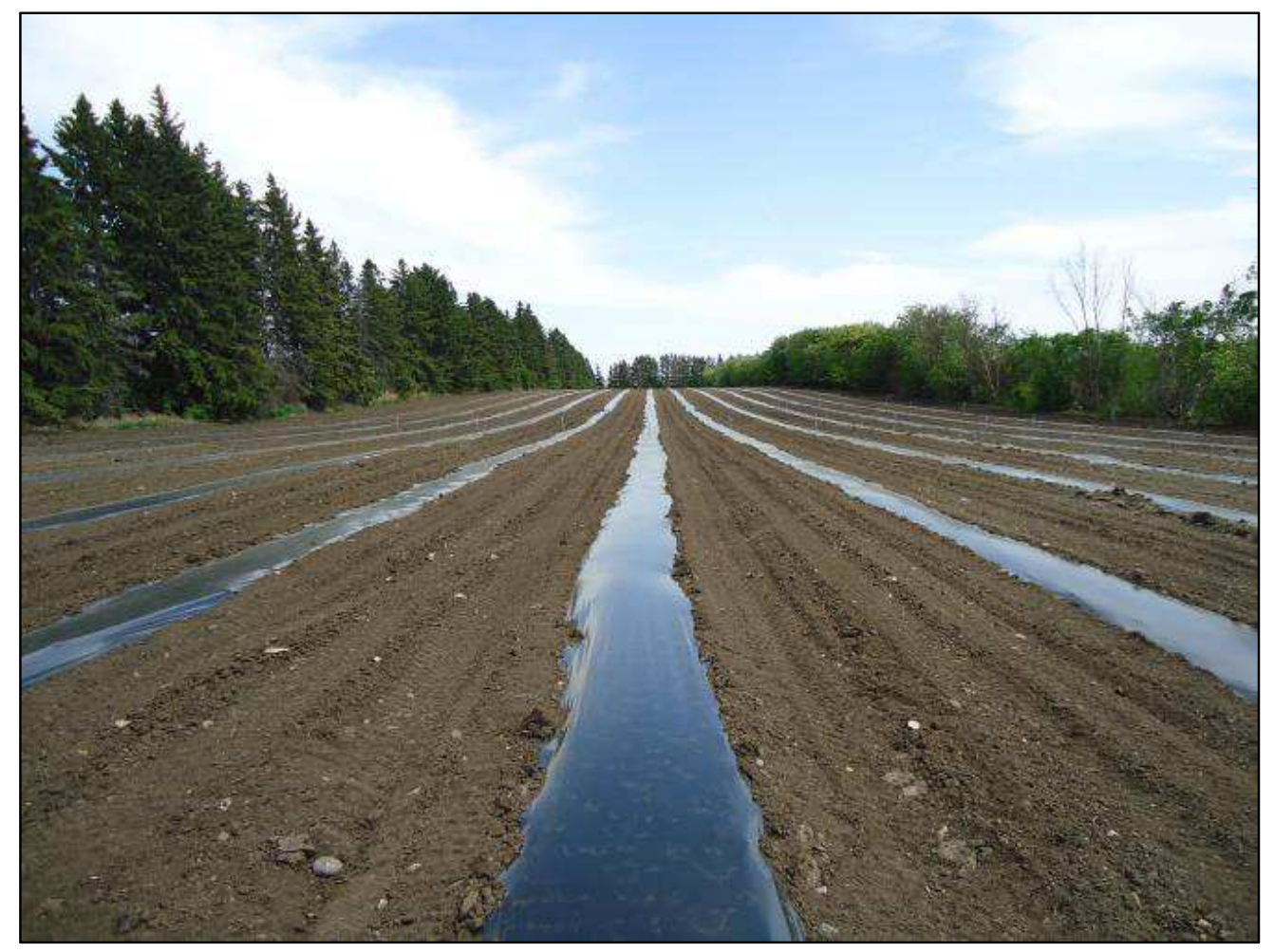

SF1 C. Laying of plastic mulch to avoid intra row weed competition.

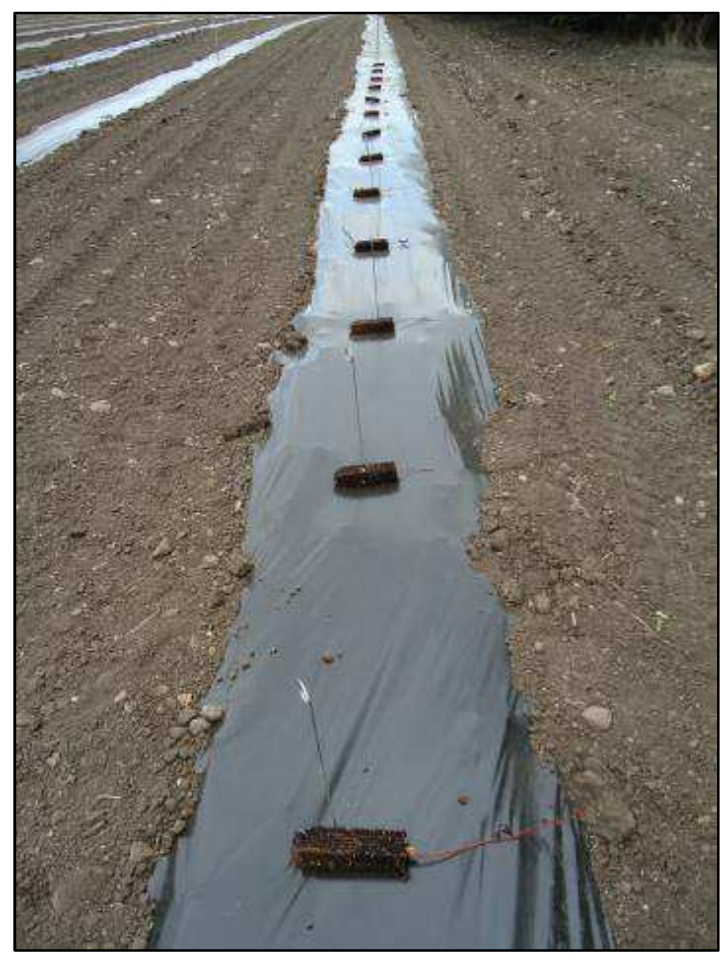


bioRxiv preprint doi: https://doi.org/10.1101/057745: this version posted June 8. 2016. The copvriaht holder for this preprint (which was not certified by peer review) is the author/funder, who has granted bioRxiv a license to display the preprint in perpetuity. It is made available under aCC-BY-ND 4.0 International license.

SF1 D. Dormant root plugs ready for planting at one metre intervals during the spring of 2012.

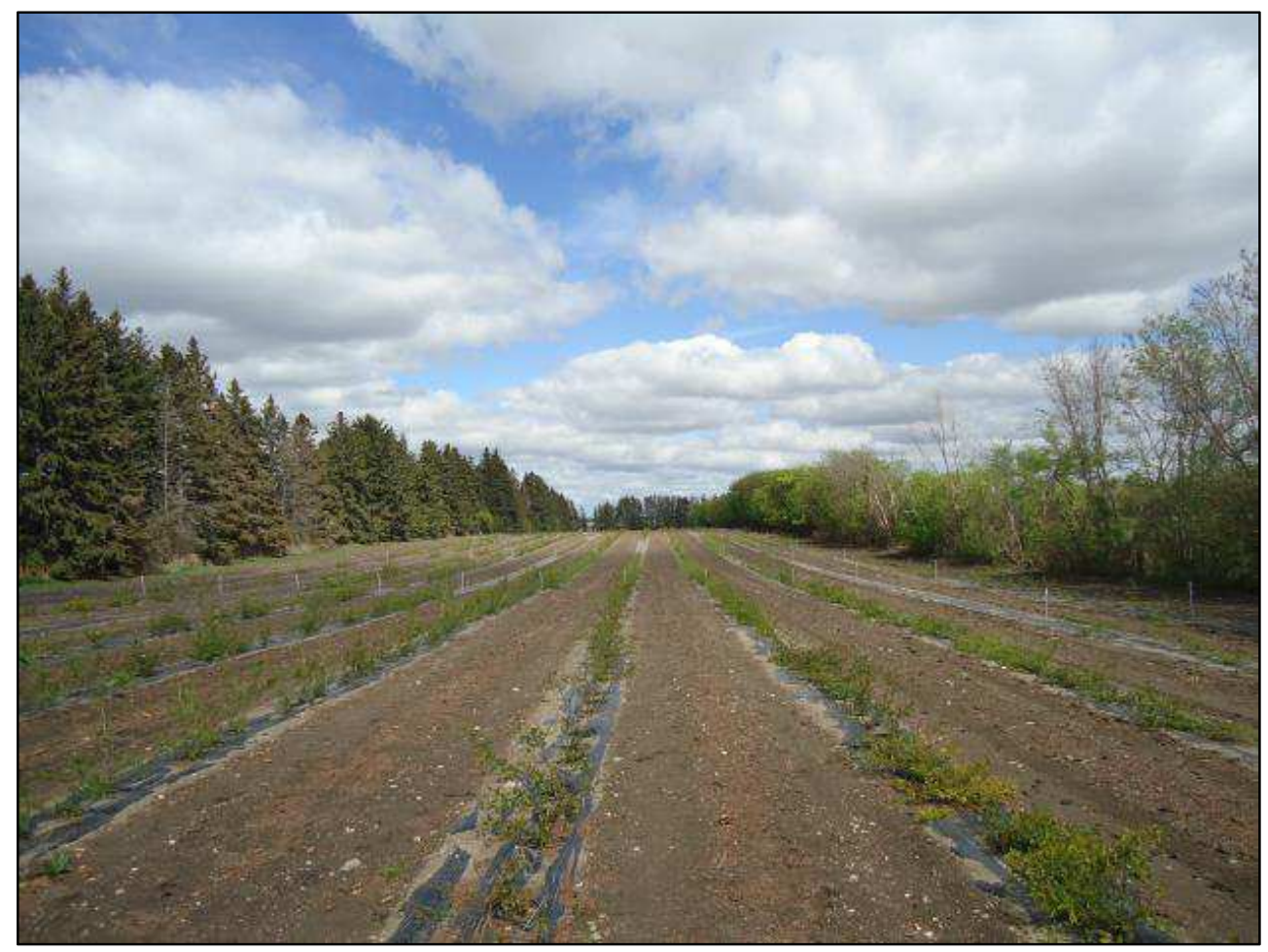

SF1 E. Uniform establishment of willow common garden during the summer of 2012.

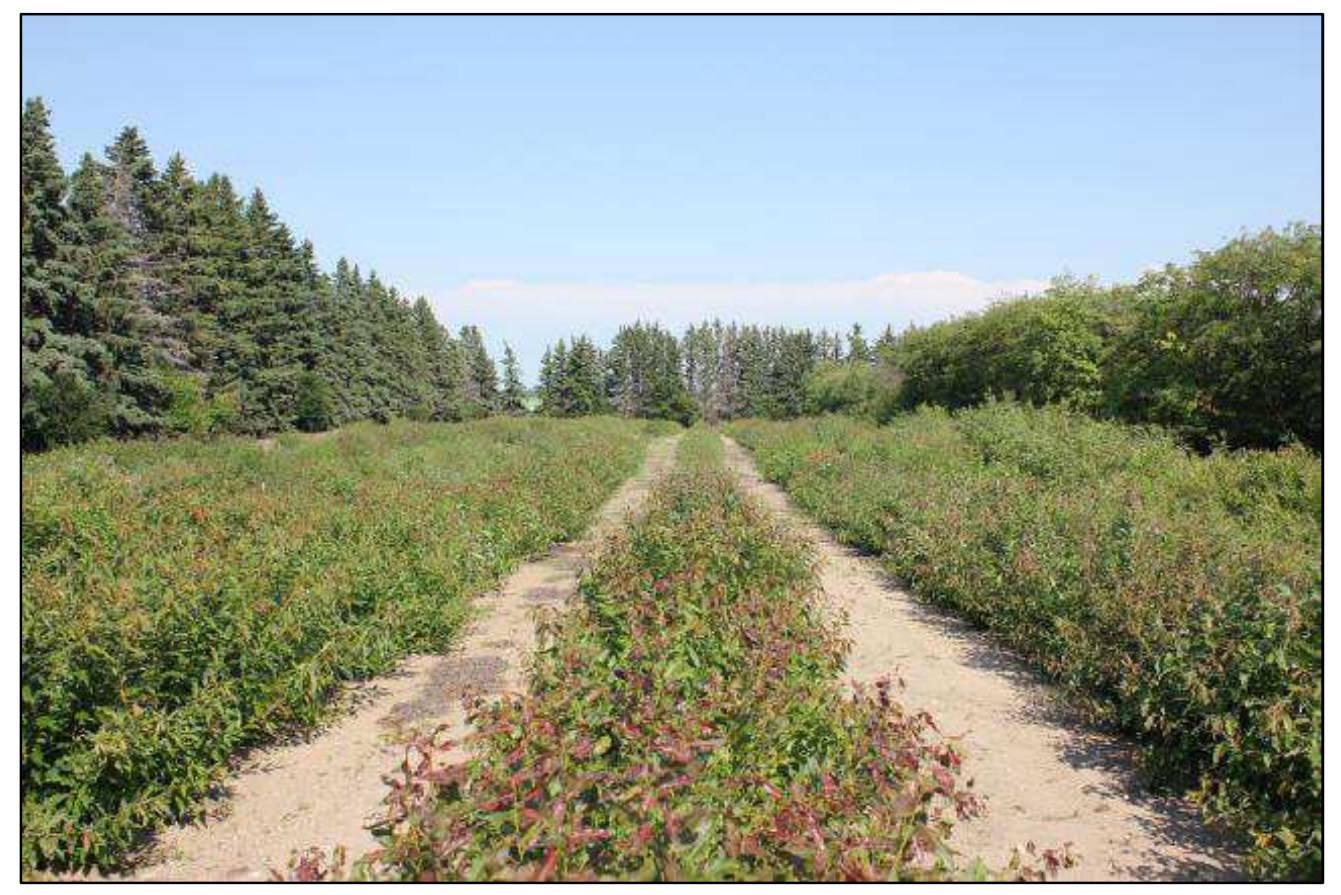

SF1 F. Willow growth during the summer of 2014. 
bioRxiv preprint doi: https://doi org/10.1101/057745; this version posted June 8,2016 . The copyright holder for this preprint (which was not certified by peer review) is the author/funder, who has granted bioRxiv a license to display the preprint in perpetuity. It is made available under aCC-BY-ND 4.0 International license.

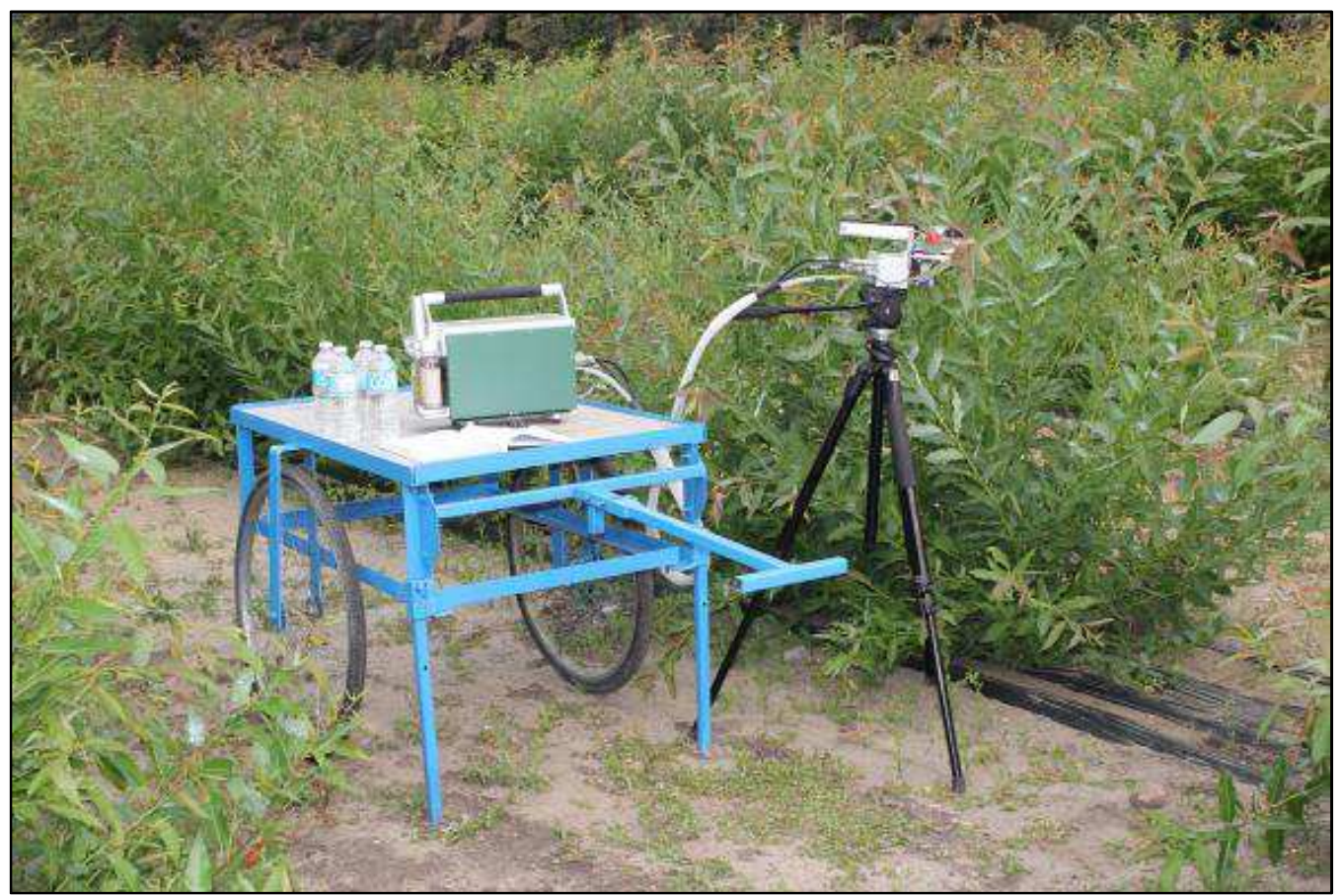

SF1 G. Gas exchange measurement during active growth in the summer of 2014. 